\title{
BACAAN KEAGAMAAN AKTIVIS KAMPUS DI UNIVERSITAS NEGERI JAKARTA (UNJ): Ide-Ide dan Transmisi
}

\section{RELIGIOUS READING MATERIALS OF CAMPUS ACTIVIST IN JAKARTA STATE UNIVERSITY (UNJ): Ideas and Transmission}

\author{
Asep Saefullah \\ Puslitbang Lektur, Khazanah Keagamaan, dan Manajemen Organisasi \\ Badan Litbang dan Diklat Kementerian Agama RI \\ Jl. MH Thamrin No. 6 Jakarta Pusat \\ asepfm@yahoo.com
}

Naskah diterima 25 April 2017, direvisi 24 Mei 2017, disetujui 5 Juni 2017

\begin{abstract}
Abstrak
This paper attempts to see the religious reading materials of religious activists at Jakarta State University (UNJ). There are two matters observed, namely the content of the religious reading materials and the field of study. This study found that religious reading materials among UNJ campus activists consist of at least two major categories, namely: First, religious reading for the needs of enrichment and improvement of Islamic insight and personal needs; and second, religious reading materials related to organizational or group tendencies, in this case LDKs, including LDFs at UNJ. The fields of study can be grouped into 11 groups, plus a special section for women. The fields of study are Akidah, Al-Qur'an, Hadith, Da'wah, Worship, Education and Moral, Islamic Economics, Islamic Family, Sirah (Prophet, Companions and Tabi'in), Tazkiyatun Nafs, and Islamic Motivation. Another important point is that religious reading materials seem to stem from the thought of Syed Qutb, as seen in their five pledges, namely: God is our aim, the Messenger of Allah is or example, the Holy Qur'an is our guidance, jihad is our way of life and Shaheed in the way of God is our highest idea.
\end{abstract}

Keywords: Religious activist, religious reading materials, UNJ, Dakwah Institute

\begin{abstract}
Abstrak
Tulisan ini mencoba melihat bacaan keagamaan aktivis keagamaan di Universitas Negeri Jakarta (UNJ). Ada dua hal yang akan dilihat, yaitu isi bacaan keagamaan dan bidang kajiannya. Penelitian ini menemukan bahwa bacaan keagamaan di kalangan aktivis kampus UNJ, setidaknya terdiri atas dua ketegori besar, yaitu: Pertama, bacaan keagamaan untuk kebutuhan pengayaan dan peningkatan wawasan keislaman dan kebutuha personal; dan kedua, bacaan keagamaan yang terkait kecenderungan organisasi atau kelompok, dalam hal ini adalah LDK, termasuk LDF-LDFyang berada di kamus UNJ. Adapun bidang kajiannya, dapat dikelompokkan menjadi 11 kelompok, ditambah satu bagian yang khusus wanita. Bidang kajian tersebut adalah Akidah, Al-Qur'an, Hadis, Dakwah, Ibadah, Pendidikan dan Moral, Ekonomi Islam, Keluarga Islami, Sirah (Nabi, Sahabat dan Tabi'in), Tazkiyatun Nafs, dan Motivasi Islami. Hal penting lainnya adalah bahwa bacaan keagamaan tampaknya memiliki geneologi hingga pemikiran Syed Qutb, misalnya terlihat pada lima ikrar mereka, yaitu: Allah tujuan kami, Rasulullah teladan kami, AlQur'an pedoman kami, Jihad jalan hidup kami, Syahid di jalan Allah cita-cita kami tertinggi.
\end{abstract}

Kata kunci: Aktivis Keagamaan, bacaan keagamaan, UNJ, Lembaga Dakwah 


\section{PENDAHULUAN}

Perkembangan teknologi informasi dewasa ini telah memberikan kemudahan kepada masyarakat dalam mengakses informasi. Hampir seluruh kalangan yang "melek" teknologi telah memanfaatkan teknologi ini, tak terkecuali masyarakat akademik, dan secara lebih khusus lagi kalangan mahasiswa. Bahan bacaan, sebagai salah satu kebutuhan primer mahasiswa, saat ini dapat diperoleh secepat yang diinginkan dengan cara yang mudah, yakni dengan teknologi informasi tersebut, antara lain melalui jejaring internet. Wa bil-khusus, bahan bacaan keagamaan pun tersebar dengan cepat melalui jejaring internet ini sehingga bukan saja aksesnya yang mudah tetapi juga publikasi dan diseminasi atau penyebarannya dapat dilakukan dengan mudah pula dan "dalam tempo yang sesingkat-singkatnya."

Dengan kemudahan teknologi informasi tersebut, kebutuhan akan bahan bacaan, termasuk bacaan keagamaan, khususnya bagi mahasiswa, dan juga penyebarannya tidak semata bergantung pada bahan bacaan cetak. Informasi dan publikasinya, sebagiannya dilakukan melalui jejaring internet. Namun demikian, ketersediaan bahan bacaan berupa cetakan masih dapat ditemukan dan tetap diproduksi. Oleh karena itu, kedua bentuk publikasi tersebut, yakni dalam bentuk digital di jejaring internet dan bentuk cetak dapat ditemukan dalam realitas sosial saat ini, termasuk di kalangan akademik atau lingkungan kampus.

Bahan bacaan keagamaan di kalangan mahasiswa, dengan demikian, juga dijumpai dalam kedua bentuk tersebut. Aktivis kampus tampaknya memanfaatkan kemudahan teknologi ini dalam mengelola bahan bacaan mereka. Format digital dari bacaan keagamaan disebarkan melalui jejaring internet, dan format cetak didistribusikan melui agen dan/atau toko buku sebagaimana dulu-sebelum teknologi informasi berkembang seperti saat inidilakukan oleh kalangan penerbit.

Menurut Malik bin Nabi, dengan berkembangnya teknologi informasi saat ini, bahwa "logika abad modern sekarang ini, kesahihan suatu pemikiran bukan dibuktikan pada tataran filosofis atau moralnya, tetapi pada tataran pragmatisnya..." 1 Dalam konteks inilah, bagaimana bahan bacaan keagamaan yang tersebar luas di internet atau dunia maya tersebut memberikan nilai pragmatis kepada para pembacanya.

Seiring dengan pesatnya perkembangan tersebut tampaknya bukan hanya menarik untuk dikaji tetapi justeru sudah selayaknya segera dilakukan kajian. Berbagai bahan bacaan terus dipublikasikan dan berbagai kalangan pula yang memanfaatkannya. Mengingat begitu luas persoalan ini, maka dalam konteks tulisan ini, sasaran kajiannya difokuskan pada bahan bacaan keagamaan di kalangan mahasiswa aktivis kampus. Secara lebih khusus lagi adalah bahan bacaan keagamaan Islam mahasiswa aktivis kampus di Perguruan Tinggi Umum (PTU), yaitu di Universitas Negeri Jakarta (UNJ).

Berdasarkan latar belakang di atas, permasalahan yang dikaji dalam tulisan ini dirumuskan dalam bentuk pertanyaan berikut: 1) Apa isi buku keagamaan yang dikaji atau dibaca oleh para aktivis kampus

${ }^{1}$ Malik bin Nabi. 1994. Membangun Dunia Baru Islam, (Terj. Afif Muhammad dan Abdul Adhiem, dari Syuruth al-Nahdhah), (Bandung: Mizan), h. 220. 
di Universitas Negeri Jakarta (UNJ)?; dan 2) Bidang kajian apa yang secara umum dikaji atau dibaca oleh para aktivis kampus tersebut? Apa alasan pemilihan bahan bacaan keagamaan tersebut?

\section{Kerangka Konseptual}

Dalam kajian ini ada beberapa konsep yang perlu dijelaskan terlebih dahulu. Kajian tentang bahan bacaan keagamaan Islam mahasiswa aktivis kampus di PTU ini merupakan bagian dari "Penelitian Bacaan Keagamaan Aktivis Kampus di Perguruan Tinggi Umum." Oleh karena itu, beberapa konsep dasarnya merujuk pada rancangan penelitian tersebut. Beberapa konsep yang dimaksud sebagai berikut:2

Bacaan Keagamaan. Dalam Kamus Besar Bahasa Indonesia (KBBI), bacaan berarti "seluruh bacaan teks, baik berupa buku, majalah, maupun buletin yang menjadi bacaan oleh pembaca." 3 Pembaca yang dimaksud di sini adalah aktivis kampus di Perguruan Tinggi Umum, khususnya di Universitas Negeri Jakarta (UNJ). Termasuk bacaan di sini adalah bacaan di dunia maya atau internet dan juga versi digital (umumnya dalam format word dan pdf). Adapun maksud keagamaan adalah segala

\footnotetext{
${ }^{2}$ Untuk menyamakan persepsi dan agar tulisan ini sejalan dengan Proposal (Desai Operasional [DO]) "Penelitian Bacaan Keagamaan Aktivis Kampus di Perguruan Tinggi Umum, batasan konsep mengenai "bacaan keagamaan", "aktivis kampus", dan "Perguruan Tinggi Umum" diambil dari Mahmudah Nur, "Rancangan Proposal Penelitian Bacaan Keagamaan Aktivis Kampus di Perguruan Tinggi Umum", 2015, h. 5-6, dan dimodifikasi dengan beberapa sumber relevan lainnya.

3 Tim Penyusun. 2008. Kamus Besar Bahasa Indonesia, Jakarta: Balai Pustaka, h. 114.
}

sesuatu yang menyangkut agama. ${ }^{4}$ Bacaan keagamaan di sini tidak hanya meliputi buku yang diterbitkan, atau jurnal, majalah, dan buletin, tetapi juga mencakup bacaan digital yang berisi masalah-masalah keagamaan.

Aktivis Kampus. Kata "aktivis" memiliki arti: "Orang (terutama anggota organisasi politik, sosial, buruh, petani, pemuda, mahasiswa, wanita) yang bekerja aktif mendorong pelaksanaan sesuatu atau berbagai kegiatan di organisasinya." ${ }^{5}$ Adapun "kampus" berarti "daerah lingkungan bangunan utama perguruan tinggi (universitas, akademi) tempat seluruh kegiatan belajar-mengajar dan administrasi berlangsung."6 Sesuai arti tersebut, "Aktivis Kampus" dalam tulisan ini adalah "seseorang yang mengikuti kegiatan intra maupun ekstra keagamaan di lingkungan perguruan tinggi, khususnya mahasiswa yang mengikuti kajian-kajian keislaman disekitar kampus."”

Perguruan Tinggi Umum. Perguruan Tinggi Umum (PTU) adalah lembaga pendidikan tinggi yang tidak berbasis pada ilmu keagamaan ${ }^{8}$ dan umumnya

\footnotetext{
18.

${ }^{5}$ Tim Penyusun, Kamus Besar Bahasa Indonesia, h. 32.

${ }^{6}$ Tim Penyusun, Kamus Besar Bahasa Indonesia, h. 628.

7 Mahmudah Nur, "Rancangan Penelitian...", h. 5-6. Lihat juga Ali Akbar, "Berjuang di Jalan Dakwah, Kajian Pemetaan Buku-Buku Keagamaan di Universitas Negeri Yogyakarta", Jurnal Lektur Keagamaan, Vol. 5 (1), 2007, h. 90. Bandingkan dengan Ali Muzakir, “Tipologi Literatur Keagamaan Aktivis Muslim Kampus di Kota Jambi”, Jurnal Lektur Keagamaan, Vol. 11(2), 2013, h. 118 (117-130)

8 Tim Penelitian Lembaga Penelitian Institut Pertanian Bogor, "Kelompok Studi Keagamaan di Kampus Perguruan Tinggi Umum”, Edukasi, Vol. I (4), 2003, h. 59.
}

${ }^{4}$ Tim Penyusun, Kamus Besar Bahasa Indonesia, h. 
berada di bawah naungan Kementerian Pendidikan dan Kebudayaan, yang sekarang di bawah Kementerian Riset, Teknologi, dan Perguruan Tinggi, baik negeri maupun swasta, seperti Universitas Indonesia (UI), Universitas Negeri Jakarta (UNJ), Universitas Padjadjaran (UNPAD), dan Institut Teknologi Bandung (ITB), atau Universitas Muhammadiyah Jakarta (UMJ), Universitas Atma Jaya, Universitas Kristen Indonesia (UKI), dan Universitas Ibnu Khaldun (UIK). Adapun sasaran kajian dalam tulisan ini adalah UNJ.

\section{METODOLOGI PENELITIAN}

Lokasi yang menjadi sasaran kajian ini adalah Universitas Neger Jakarta (UNJ), yang merupakan salah satu Perguruan Tinggi Umum Negeri di Provinsi DKI Jakarta. Pemilihan lokasi ini antara lain karena berdasarkan cakupan wilayah kerja untuk Indonesia Bagian Barat, UNJ yang terletak DKI Jakarta termasuk dalam kategori yang dapat dipilih. Alasan lain, bahwa aktivitas keagamaan (baca: Islam) di kampus UNJ tergolong semarak yang dapat dilihat dari kegiatan-kegiatan keagamaan yang dilakukannya. Di antaranya, peringatan hari besar keagamaan seperti Isra Mir'raj, Nuzulul Qur'an, dan Maulid Nabi, serta sebagai salah satu PTU yang memiliki Program Studi Ilmu Agama Islam (IAI), sebagai upaya memperkokoh pembudayaan agama dan kehidupan keagamaan di lingkungan kampus. ${ }^{9}$ Demikian juga aktivitas di Masjid

${ }^{9}$ Syahidin, dkk. 2004.Pendidikan Agama Islamuntuk Perguruan Tinggi, (Jakarta: Direktorat Pembelajaran dan Kemahasiswaan, Direktorat Jenderal Perguruan Tinggi, Kementerian Pendidikan dan kebudayaan), h. 292. Lihat http://fis.unj.ac.id/?page_id=129.
Kampus UNJ, dengan komunitasnya yang bernama "Komunitas Studi Pemikiran Islam Universitas Negeri Jakarta," disingkat Kupas UNJ, yang merupakan wadah bagi mahasiswa UNJ untuk mempelajari pemikiran Islam. ${ }^{10}$

Metode yang digunakan dalam tulisan ini adalah deskriptif-analitis dengan pendekatan kualitatif.Dengan menggunakan metode dan pendekatan tersebut, tulisan ini menyajikan literatur yang dibaca dan dikaji oleh kelompok atau aktivis keagamaan di kampus, khusunya di UNJ, secara deskriptif. Data dari lapangan, berupa literatur atau buku-buku keagamaan kemudian dianalisis dari segi isi dan wacananya. Dari segi isi terkait dengan bidang kajiannya, sedangkan dari segi wacana dianalisis kecenderungan pemikirannya. ${ }^{11}$

\section{HASIL DAN PEMBAHASAN}

\section{Sejarah Ringkas Universitas Negeri Jakarta (UNJ)}

Universitas NegeriJakarta (UNJ) sebelum menjadi universitas merupakan Institut Keguruan Ilmu Pendidikan (IKIP) Jakarta yang terletak di Rawamangun, Jakarta Timur. IKIP Jakarta didirikan pada $16 \mathrm{Mei}$ 1964. Di antara latar belakang didirikannya IKIP adalah bahwa Pemerintah Indonesia

\footnotetext{
${ }^{10}$ http://kupasunj.tumblr.com/. Berbasarkan penelusuran lapangan dan wawancara dengan beberapa aktivis dan pengurus Lembaga Dakwah Kampus (LDK) di UNJ, sumber atau rujukan untuk profil dan kegiatan kelembagaan LDK ini lebih banyak bersifat online, seperti dalam situs http://kupasunj. tumblr.com/. Oleh karena itu, tidak dapat dihindari banyaknya pengutipan dari sumber online tersebut. Wawancara terpisah dengan Hadi al-Hadi, pada 7 September 2015, dan Hadi Fadila, pada 11 September 2015, di Kampus UNJ, Rawamangun, Jakarta Timur.

${ }^{11}$ Ali Akbar, "Berjuang di Jalan Dakwah...", h. 90.
} 
pada masa awal kemerdekaan merasakan kekurangan tenaga kependidikan di semua jenjang dan jenis lembaga pendidikan. Untuk mengatasi permasalahan tersebut, pemerintah mendirikan kursus-kursus pendidikan guru. Pada tahun 1950-an, di atas jenjang pendidikan menengah didirikan Kursus B-I, B-II, dan PGSLP yang bertugas menyiapkan guru-guru untuk sekolah lanjutan.

Berbagai usaha untuk meningkatkan mutu guru dan jumlahnya terus dilakukan, antara lain dengan mendirikan Perguruan Tinggi Pendidikan Guru (PTPG) berdasarkan Keputusan Menteri P dan K, No. 382/Kab Tahun 1954. PTPG didirikan di empat kota, yaitu Batusangkar, Bandung, Malang, dan Manado. Dengan berdirinya PTPG, ada dua macam lembaga pendidikan yang menghasilkan guru, yakni Kursus B-I/BII/PGSLP dan PTPG. Untuk menghindari dualisme, kedua lembaga ini diintegrasikan secara bertahap. Pada 1957, PTPG diintegrasikan ke dalam Fakultas Keguruan dan Ilmu Pendidikan (FKIP) pada universitas terdekat. Setahun kemudian, Fakultas Pedagogikjuga diintegrasikan ke dalam FKIP, berdasarkan PP No. 51 Tahun 1958. Pada 1961, Kursus B-I dan B-II pun diintegrasikan ke dalam FKIP di bawah Kementerian Pendidikan Tinggi berdasarkan Keputusan Menteri P dan K. No. 6 dan 7, tanggal 8 Pebruari 1961. Tujuannya adalah untuk menghasilkan guru sekolah menengah. Pada 1963, Kementerian Pendidikan Dasar mendirikan Institut Pendidikan Guru (IPG), yang juga untuk menghasilkan guru sekolah menengah. Dualisme pun muncul lagi sehingga kurang efektif dan mengganggu manajemen pendidikan guru. Untuk mengatasinya, kursus B-I dan B-II di Jakarta diintegrasikan ke dalam FKIP Universitas Indonesia.

Melalui Keputusan Presiden RI No. 1 tahun 1963 tanggal 3 Januari 1963, ditetapkan integrasi sistem kelembagaan pendidikan guru. Salah satu butir pernyataan Keppres tersebut adalah bahwa Surat Keputusan ini berlaku sejak 16 Mei 1964, yang kemudian dinyatakan sebagai hari lahirnya IKIP Jakarta. FKIP Universitas Indonesia dan IPG Jakarta diintegrasikan dan berubah menjadi IKIP Jakarta. ${ }^{12}$

Seiring dengan perkembangan zaman, berbagai perguruan tinggi di Indonesia mengalami perluasan mandat. IKIP Jakarta adalah salah sayu yang mengalami perluasan mandat. Pada 4 Agustus 1999, IKIP Jakarta berubah menjadi Universitas Negeri Jakarta (UNJ) sehingga mencakup ilmu kependidikan dan non kependidikan. Perubahan ini ditetapkan melalui Keputusan Presiden (Keppres) Nomor: 093/1999. Peresmiannya dilaksanakan pada 31 Agustus 1999 oleh Presiden Republik Indonesia pada saat itu di Istana Presiden. Akan tetapi, sebagai upaya mempertahankan nilai sejarah, Hari Jadi UNJ tidak ditetapkan pada saat berubahnya menjadi UNJ tetapi ditetapkan sesuai dengan Hari Jadi IKIP Jakarta, yaitu 16 Mei 1964. ${ }^{13}$

${ }^{12}$ Tim Penyusun, Pedoman Akademik 2014/2015 Fakultas Ilmu Pendidikan Universitas Negeri Jakarta, (Jakarta: Univrsitas Negeri Jakarta, 2014), h. 15. Lihat juga Tim Penyusun, "Sejarah UNJ", http://www.unj. ac.id/halaman/profil/sejarah, Jakarta: Admin. Web UNJ. Dikases 07/09/2015.

${ }^{13}$ Tim Penyusun, Pedoman Akademik 2014/2015 Fakultas Ilmu Pendidikan..., h. 16. 


\section{Aktivitas Keagamaan di UNJ}

Aktivitas keagamaan di UNJ tegolong mendapat perhatian serius, antara lain dengan diformalkannya pendidikan agama Islam. Pengajaran formal ini tidak hanya dalam bentuk Mata Kuliah tetapi juga diwujudkan dalam bentuk program studi, yaitu Program Studi Ilmu Agama Islam (IAI) yang berada di Fakultas Ilmu Sosial (FIS). Prodi ini telah terakreditasi B oleh Badan Akreditasi Nasional Perguruan Tinggi (BAN-PT) pada tahun 2012 sesuai dengan Keputusan BAN-PT Nomor: 017/BAN-PT/Ak$\mathrm{XV} / \mathrm{S} 1 / \mathrm{VI} / 2012 .{ }^{14}$ FIS UNJ sendiri memiliki visi "Pada tahun 2020 Fakultas Ilmu Sosial Universitas Negeri Jakarta menjadi fakultas yang mampu menghasilkan lulusan yang unggul, kompetitif dan berkarakter dalam bidang pendidikan ilmu sosial dan ilmu-ilmu sosial." 15 Di negea yang mayoritas Muslim seperti Indonesia, sudah seharusnya PAl "menempati posisi "kunci" dan terintegrasi secara fungsional dengan berbagai disiplin ilmu atau bidang studio Kenyataannya PAI masih sering dianggap berada pada posisi

\footnotetext{
${ }^{14}$ Keputusan Badan Akreditasi Nasional Perguruan Tinggi, Nomor: 017/BAN-PT/Ak-XV/ S1/VI/2012 Tentang Status, Nilai, Peringkat, dan Masa Berlaku Hasil Akreditasi Program Sarjana Perguruan Tinggi, 29 Juni 2012. Lihat juga http://fis. unj.ac.id/?page_id $=129$.

${ }^{15}$ Tim Penyusun. 2016. Pedoman Akademik 20162017 Fakultas Ilmu Sosial, (Jakarta: Universitas Negeri Jakarta), h. 123. Adapun mata kuliah "Pendidikan Agama Islam” (PAI; Kode 4123-016-2; 2 SKS), dimaksudkan untuk "Menumbuhkan masalahmasalah religi secara akademis, kritis, dan rasional sesuai dengan ajaran dan agamanya. Berkemauan mengabdikan kehidupannya pada pekerjaan ilmiah untuk kepentingan sesama di segala aspek kehidupan dan menjalani kehidupan sesuai dengan ajaran dan pemahaman nilai religinya.", h. 155.
}

"pinggiran" dan teralienasi dari bidang studi lainnya." 16

Sejalan dengan visi FIS, visi Prodi IAI UNJ adalah "Menjadi Program Studi unggulan di tingkat nasional pada tahun 2020 dan internasional pada tahun 2025 dalam bidang Pendidikan Agama Islam dan Komunikasi Penyiaran Islam berdasarkan pemahaman Islam moderat (al-wasathiyyah) yang memadukan khazanah pemikiran Islam klasik dan modern." ${ }_{17}$

Untuk mewujudkan visinya, dirumuskan misinya sebagai barikut: a) Menyelenggarakan pendidikan dan pembelajaran yang mampu menghasilkan tenaga pendidik Pendidikan Agama Islam dan tenaga Komunikasi Penyiaran Islam, b) Menyelenggarakan pendidikan dan pembelajaran tentang khazanah pemikiran Islam klasik dan modern melalui sumber aslinya, c) Menyelenggarakan kegiatan penelitian dalam bidang Pendidikan Agama Islam dan Komunikasi Penyiaran Islam dengan menggunakan paradigma Islam klasik dan modern, d) Melaksanakan kegiatan pengabdian masyarakat dalam bidang Pendidikan Agama Islam dan Komunikasi Penyiaran Islam dalam upaya pengembangan kehidupan beragama

${ }^{16}$ Marzuki. 1997. "Pendidikan Agama Islam di Perguruan Tinggi Umum dan Pemberdayaan Masyarakat Indonesia", Cakrawala Pendidikan, No.1, Tahun XVI, h. 96. (93-101)

${ }^{17}$ Tim Penyusun, Pedoman Akademik 20162017 Fakultas Ilmu Sosial, h. 256. Dalam sumber: http://fis.unj.ac.id/?page_id=129, visinya adalah "Menjadi Program Studi unggulan di tingkat nasional pada tahun 2015 dan internasional pada tahun 2025 dalam bidang Pendidikan Agama Islam dan Komunikasi Penyiaran Islam berdasarkan pemahaman Islam moderat (al-wasațiyyah) yang memadukan khazanah pemikiran Islam klasik dan modern." 
yang moderat, terbuka, dan maju, e) Melaksanakan kegiatan kerjasama dalam bidang Pendidikan Agama Islam dan Komunikasi Penyiaran Islam yang saling menguntungkan dengan lembaga swasta dan pemerintah baik di dalam maupun di luar negeri sebagai perwujudan dari pelaksanaan Tri Dharma Perguruan tinggi, f) Menyelenggarakan pendidikan dan pembelajaranyangmenjunjungtinggiakhlak dan nilai-nilai kemanusiaan dalam setiap aspek kehidupan, g) Menyelenggarakan pendidikan dan pembelajaran yang dapat menghasilkan sarjana yang mampu mengkomunikasikan pemahaman Islam moderat (al-wasathiyyah). ${ }^{18}$

Kegiatan keagamaan lain adalah kegiatan-kegiatan yang terkait dengan pendidikan agama Islam selain pendidikan dan pengajaran, yaitu peringatan hari besar keagamaan (baca: Islam), seperti Isra' Mi'raj, Nuzulul Qur'an, dan Maulid Nabi; dan kagiatan ekstra kurikuler, seperti Lembaga Dakwah Kampus (LDK) beserta Lembaga Dakwah di tiap-tiap fakultas atau Lembaga Dakwah Fakultas (LDF), kelompok studi keagamaan, dan festival keagamaan.

Salah satu kegiatan yang terkait dengan pendidikan agama Islam, di UNJ pernah diselenggarakan Kongres Nasional Pendidikan Agama Islam (KONASPAI) III Asosisasi Dosen Pendidikan Agama Islam seluruh Indonesia (ADPISI) tahun 2011. Kongres ini dihadiri oleh Wakil Menteri Pendidikan danKebudayaan (Wamendikbud) pada masa itu, Prof Dr Ir Musliar Kasim, MSc., dan memberikan sambutan. Dalam

${ }^{18}$ Tim Penyusun, Pedoman Akademik 2016-2017 Fakultas Ilmu Sosial, h. 256. Lihat juga http://fis.unj. ac.id/?page_id=129. sambutannya, ia meminta kepada para dosen ilmu agama yang tergabung dalam ADPISI, "agar mampu mendorong mewujudkan karakter mahasiswa sehingga tumbuh karakter yang baik dan akhlak mulia." ${ }_{19}$

Sedangkan kegiatan ekstra kurikuler antara lain dilaksanakan oleh Komunitas Studi Pemikiran Islam Universitas Negeri Jakarta (Kupas UNJ). Kupas UNJ menjadi wadah bagi mahasiswa UNJ untuk mengembangkan diri dan memperluas wawasan keagamaan, khususnya pemikiran Islam. Dewan Kemakmuran Masjid Nurul Irfan UNJ bekerjasama dengan Kupas UNJ pernah menyelenggarakan Bedah Buku MUI berjudul "Mengenal dan Mewaspadai Penyimpangan Syi'ah di Indonesia" pada Sabtu, 12 April 2014 di Masjid Nurul Irfan UNJ, Rawamangun, Jakarta Timur. ${ }^{20}$

Kegiatan keagamaan yang tergolong sistematis dan masif antara lain dilakukan oleh Forum Studi Islam Al-Biruni LDF (Fakultas Teknik), yaitu dengan mencanangkan apa yang disebut "9 Budaya Muslim UNJ”, yaitu: 1) SAW (Salat Awal Waktu), 2) TIBAS (Tilawah Ba'da Salat), 3) SPD (Setiap Pagi Duha), 4) SKS (Senin Kamis Saum), 5) GT-5S (Gerakan Tebar Senyum Salam Sapa Sopan Santun), 6) GEMAR INFAQ (Gerakan Mari Berinfaq), 7) GST (Gerakan Setengah Tujuh), 8) JUMTIH (Jum'at Putih Bersih), dan 9) GEMES (Gerakan Muslimah Berhias Syar'i). Gerakan lain yang dapat dikatakan cukup spektakuler adalah apa

\footnotetext{
${ }^{19} \mathrm{http}: / / w w w . a n t a r a n e w s . c o m /$ berita/285219/dosenilmu-agama-islam-diminta-dorong-karakter-mahasiswa: Dosen ilmu agama Islam diminta dorong karakter mahasiswa, Kamis, 17 November 2011 20:11 WIB, Pewarta: Ruslan Burhani. Diakses 02/09/2015.

${ }^{20}$ Berita ini dimuat dalam http://kupasunj.tumblr. com/
} 
yang dilakukan BEM Fakultas Matematikan dan IPA (MIPA) yang membuat aturan bahwa mahasiswi baru yang beragama Islam wajib mengenakan jilbab, yakni pada Masa Pengenalan Akademik (MPA) yang disebut dengan Ospek. ${ }^{21}$

\section{Organisasi Keagamaan dan Kelompok Studi Agama Internal Kampus UNJ}

\section{Kategori Organisasi Keagamaan di UNJ}

Kegiatan keagamaan di UNJ dapat dikelomppokkan setidaknya menjadi tiga jenis, yaitu: 1) Kegiatan Akademik Keagamaan,2)KegiatanLembaga Keagamaan Mahasiswa, dan 3) Kegiatan Kelompok Studi Agama. Kegiatan jenis pertama, yaitu Kegiatan Akademik Keagamaan berwujud dalam Program Studi Ilmu Agama Islam pada Fakultas Ilmu Sosial, sebagaimana telah dijelaskan di atas. Kegiatan jenis kedua adalah kegiatan-kegiatan yang dilakukan oleh Lembaga Dakwah, baik tingkat universitas, yakni LDK (Lembaga Dakwah Kampus) maupun fakultas, yaitu LDF (Lembaga Dakwah Fakultas). Jenis ketiga adalah kelompok studi, yang juga berada di tingkat universitas maupun di tingkat fakultas. Kelompok studi tingkat universitas antara lain Kupas UNJ. Adapun kelompok studi agama di tingkat fakultas umumnya merupakan bagian dari atau bahkan sebagai nama dari LDF, misalnya Forum Studi Islam (FSI) Al-Biruni, FSI Khidmatul Ummah, FSIKU, Forum Mahasiswa Islam (FORMASI) Tarbawi, Islamic Center Al-Ijtima'i, BSO

\footnotetext{
${ }^{21}$ Andi Ryansyah, "Jilbab dan MPA di FMIPA UN", dalam http://kupasunj.tumblr.com/
}

Al-Iqtishodi, Kerohanian Islam Mahasiswa (KARISMA) Fakultas Ilmu Keolahragaan. ${ }^{22}$

\section{Profil Lembaga Dakwah Kampus (LDK) SALIM UNJ}

Lembaga Dakwah di tingkat universitas di UNJ dinamakan LDK Salim UNJ. “Lembaga Dakwah Kampus UNJ merupakan salah satu unit kegiatan mahasiswa di UNJ yang berasaskan Islam, suatu lembaga yang dikelola oleh mahasiswa muslim untuk mengkoordinir dan mengembangkan kegiatan keislaman di UNJ. Sejak didirikan pada tahun 1409 H/1989 M, organisasi ini bersifat kekeluargaan yang mengutamakan persaudaraan antarsesama muslim dan toleransi dengan mahasiswa nonmuslim UNJ." ${ }^{23}$ Di bawah LDK ada Lembaga Dakwah di tingkat fakultas atau LDF dan Lembaga Semi Otonom (LSO). Beberapa LDF dan LSO yang ada di UNJ antara lain:

Masjid Ulul Albaab (MUA). Masjid Ulul Albaab (MUA) diresmikan pada Jum'at, 4 September 1992, di Jakarta. MUA berfungsi sebagai pusat kegiatan keagamaan atau syiar dan peribadatan di kampus UNJ khususnya di kampus B, yang meliputi

${ }^{22}$ Unit kegiatan mahasiswa di beberapa Perguruan Tinggu Umum (PTU) seperti Institut Pertanian Bogor (IPB), Universitas Pakuan (UNPAK), Universitas Andalas (UNAND), dan Universitas Sriwijaya (UNSRI) terdiri atas empat jenis, yaitu: 1) Unit kegiatan mahasiswa dalam lembaga formal dan mendapatgkan anggaan biaya dari universitas, 2) Kelompok kajian keagamaan di tingkat dakultas dan departemen/jurusan, 3) kelompok jamaah masjid kampus, dan 4) kelompok belajar formal yang terkait dengan kegiatan kurikuler. Lihat Tim Penelitian Lembaga Penelitian Institut Pertanian Bogor, "Kelompok Studi Keagamaan di Kampus Perguruan Tinggi Umum”, h. 70.

23"Profil LDK Salim UNJ", http://salimunj.com/ s2/2012/05/12/profil-ldk-salim-unj/. Lihat juga http:// www.unj.ac.id/pr3/?page_id=457. Diakses 07/09/2015. 
Fakultas Matematika dan Ilmu pengetahuan Alam dan Fakultas Ilmu Keolahragaan. Keberadaan Masjid ini memberikan nuansa dan suasana Islami di kampus B, khususnya di dua fakultas tersebut. Luas tanah MUA sekitar $200 \mathrm{~m}^{2}$ (dua ratus meter persegi). Kegiatan-kegiatan rutin MUA, di antaranya: Studi Islam Komprehensif, Mentoring Keislaman, Peringatan Hari-Hari Besar Islam (PHBI), Kajian Rutin, Aksi Sosial, TPA dan TK, Kursus Bahasa Arab, Program Tahsin (Perbaikan Bacaan Al-Qu'an) dan Pembinaan Ruhiyah pada kegiatan MABIT (Malam Bina Iman dan Taqwa).

Forum Studi Islam (FSI) Al-Biruni. Forum Studi Islam (FSI) Al-Biruni adalah lembaga keislaman dan sebagai Organisasi Mahasiswa (ORMAWA) di Fakultas Teknik UNJ. Setiap mahasiswa muslim FT UNJ adalah anggota FSI Al-Biruni dan berhak menjadi bagian dari dan dalam kegiatan FSI Al-Biruni. FSI Al-Biruni tidak hanya di bidang dakwah saja, tetapi juga sebagai wadah berdiskusi, mencari ilmu, dan sebagai sarana menjalin persaudaraan sesama anggotanya.

Badan Semi Otonom (BSO) Al-Iqtishodi. BSO Al-Iqtishodi didirikan pada 20 April 2001, sebagai Lembaga Kerohanian Islam (ROHIS) di Jurusan Ekonomi, FIS. Tahun 2002, mahasiswa Ekonomi mulai mengenal Musala Al-Iqtishodi di Jurusan Ekonomi, yakni di Gedung N. Periode 2003/2004, program kerja musala ini dikoordinasikan dengan Musala Al-Ijtima'i FIS (sekarang ICA FIS). Pada Periode 2004/2005, Musala Al-Iqtishodi mulai merintis pengenalan dan "pencitraaan lembaga" kepada mahasiswa Ekonomi. Pada 2005, Jurusan Ekonomi menjadi menjadi
Fakultas Ekonomi sehingga berpengaruh juga pada lembaga kemahasiswaan. ${ }^{24}$

Adapun Lembaga Semi Otonom (LSO) LDK UNJ di antaranya: 1) Qur'an Institute UNJ. Lembaga ini didirikan pada Jum'at, 17 Juni 2005 dan diresmikan pada Jum'at, 17 Agustus 2008. Di lingkungan kampus UNJ, Qur'an Institute UNJ memiliki program khusus mempelajari, baik membaca, menghafal, maupun mengkaji Al-Qur'an. Qur'an Institute UNJ merupakan penggabungan dari lembaga-lembaga Tahfizh Al-Qur'an Fakultas se-UNJ. Sebelumnya dakwah AlQur'an dilakukan di tingkat fakultas masingmasing. Setelah penggabungan ini, dakwah Al-Qur'an dipusatkan di tingkat universitas dan diamanahkan pada Qur'an Institute UNJ. Qur'an Institute UNJ kemudian menjadi lembaga formal kampus dan sebagai mitra LDK UNJ. Akhir Januari 2009 menjadi LSO QI LDK UNJ. ${ }^{25}$

2) Nuraniku UNJ. Nuraniku adalah salah satu LSO LDK UNJ yang bergerak di bidang jurnalistik Islam. Nuraniku diberntuk ketika dilaksanakan Islamic Journalistic Training 1 (IJT 1) pada Agustus 2004, yang diselenggarakan oleh Departemen Media Muslim Crisis Center (M2C2). M2C2 sendiri saat ini menjadi Humas LDK. ${ }^{26}$

Terkait dengan wacana keagamaan perlu dijelaskan di sini bahwa mahasiswa yang dipandang sebagai agent of change (agen perubahan) yang aktif dalam organisasi

${ }^{24}$ Masjid Ulul Albaab (MUA), Forum Studi Islam (FSI) Al-Biruni, dan BSO Al-Iqtishodi, lihat http:// salimunj.com/s2/2012/05/23/lembaga-dakwah-fakultas/. Diakses 02/09/2015.

${ }^{25} \mathrm{http}: / /$ salimunj.com/s2/2012/05/21/lembaga-semiotonom-ldk-unj/

${ }^{26} \mathrm{http}: / /$ salimunj.com/s2/2012/05/21/lembaga-semiotonom-ldk-unj/ 
keagamaan, sebagian mereka diasosiasikan pada fundamentalisme dan radikalisme. Saifuddin memandang bahwa mahasiswa Perguruan Tinggi Umum relatif lebih mudah direkrut ke dalam gerakan tersebut daripada mahasiswa Perguruan Tinggi Agama. Ia menulis:

"Perguruan tinggi umum lebih mudah menjadi target rekrutmen gerakan-gerakan radikal, sementara perguruan tinggi berbasis keagamaan diangap lebih sulit. Kalau ternyata faktanya menunjukkan bahwa gerakan radikal juga sudah marak dan subur di kampus-kampus berbasis keagamaan, maka ini dapat membuktikan dua hal. Pertama, telah terjadi perubahan di dalam perguruan tinggi berbasis keagamaan itu sendiri. Kedua, telah terjadi metamorfosa bentuk dan strategi gerakan di internal gerakan-gerakan radikal." ${ }^{27}$

Walaupun tidak selalu mudah untuk mengasosiasikan suatu kelompok pada kelompok lain serta menilai kecenderungan wacana dan gerakannya tetapi ada beberapa indikator yang dapat diamati. Salah satunya yang relatif cukup nyata dan dapat dianalis adalah bahan bacaan. Dalam konteks pengamatan ideologi dan transmisi pemikiran, bahan bacaan dapat dijadikan salah satu alat untuk membuktikan ada tidaknya keterkaitan dan kesinambungan pemikiran maupun gerakan antara satu kelompok dengan kelompok lainnya. Oleh karena itu, mengamati bacaan keagamaan di LDK dan LDF-LDF UNJ dapat pula dilihat hubungan pemikiran dan gerakannya dengan organisasi-organisasi sosial-

${ }^{27}$ Saifuddin, "Radikalisme di Kalangan Mahasiswa (Sebuah Metamorfosa Baru)", Analisa, Jurnal Studi Keislaman, Vol. 9(1), IAIN Raden Intan Lampung, Juni 2011, h. 28-29. (17-32), keagamaan atau partai-partai politik di luar kampus. ${ }^{28}$

\section{Bacaan Keagamaan Aktivis Kampus UNJ \\ Ragam Bacaan Keagamaan}

Lembaga dakwah di UNJ, sebagaimana dijelaskan di atas, meliputi lembaga dakwah tingkat universitas yang disebut Lembaga Dakwah Kampus (LDK) Salim UNJ dan tingkat fakultas dengan nama masingmasing, yaitu Lembaga Dakwah Fakultas (LDF). Berdasarkan penelusuran data dari angket yang disebarkan kepada beberapa anggota dan pengurus, baik LDK maupu LDF-LDF diperoleh data sebagai berikut:

Tabel 1

Bacaan Keagamaan Aktivis Kampus sebagaimana Disebutkan oleh Mahasiswa Anggota/Pengurus LDK/LDF di UNJ

\begin{tabular}{|c|c|c|c|}
\hline No & Judul Buku & Pengarang & Alasan \\
\hline 1 & $\begin{array}{l}\text { Jiwa-Jiwa Gagah } \\
\text { yang Pantang } \\
\text { Menyerah }\end{array}$ & A. Mukhlis & $\begin{array}{l}\text { Motivasi sebagai } \\
\text { aktivis dan pemuda }\end{array}$ \\
\hline 2 & Sirah Nabawiyah & $\begin{array}{l}\text { Syekh } \\
\text { Shafiyurrahman }\end{array}$ & $\begin{array}{l}\text { Refleksi, cari } \\
\text { wawasan, Sarana } \\
\text { Muhasabah }\end{array}$ \\
\hline 3 & $\begin{array}{l}20 \text { Kritik untuk } \\
\text { Kaum Liberal }\end{array}$ & M. Ardiansyah & $\begin{array}{l}\text { Wawasan, ingin } \\
\text { tahu }\end{array}$ \\
\hline 4 & $\begin{array}{l}\text { Negeri Para } \\
\text { Bedebah } \\
\end{array}$ & Tereliye & $\begin{array}{l}\text { Menarik untuk } \\
\text { dibaca }\end{array}$ \\
\hline 5 & $\begin{array}{l}\text { Momitmen Dai } \\
\text { Sejati }\end{array}$ & $\begin{array}{l}\text { Muhammad } \\
\text { Abduh }\end{array}$ & $\begin{array}{l}\text { Materi untuk } \\
\text { Halaqah }\end{array}$ \\
\hline 6 & Fiqih Dakwah & Jum'ah Amin & - \\
\hline 7 & $\begin{array}{l}\text { Bagaimana } \\
\text { Menyentuh Hati }\end{array}$ & Abbas As-Sisi & Isinya menarik \\
\hline 8 & Islam Liberal & Akmal Syarif & - \\
\hline 9 & $\begin{array}{l}\text { Pesan-Pesan } \\
\text { Rasulullah } \\
\text { sebelum Wafat }\end{array}$ & Said bin Ali & Untuk belajar \\
\hline 10 & Islam Nusantara & Said Aqil Siraj & Untuk belajar \\
\hline
\end{tabular}

${ }^{28}$ Transmisi pemikiran atau ideologi melalui bacaan juga pernah ditemukan pada buku-buku keagamaan yang dibaca dan dijadikan rujukan oleh aktivis Badan Kerohanian Islam Mahasiswa (BKIM) di Institut Pertanian Bogor. Lihat Asep Saefullah, "Peta Lektur Keagamaan pada Kelompok Keagamaan Islam di IPB: Benang Merah Gerakan Islam Asasi”, Jurnal Lektur Keagamaan, Vol. 6 (1), 2008, h. 91-124, khususnya h. 118. 


\begin{tabular}{|c|c|c|c|}
\hline 11 & $\begin{array}{l}\text { Lapis-Lapis } \\
\text { Keberkahan }\end{array}$ & Salim A. Fillah & $\begin{array}{l}\text { Karena bukunya } \\
\text { dan penulisnya }\end{array}$ \\
\hline 12 & Api Tauhid & Habiburrahman & - \\
\hline 13 & $\begin{array}{l}\text { Happy Ending Full } \\
\text { Barokah }\end{array}$ & Solikhin Abu & $\begin{array}{l}\text { Sesuai dengan } \\
\text { kondisi kekinian }\end{array}$ \\
\hline 14 & $\begin{array}{l}\text { Dalam Dekapan } \\
\text { Ukhuwah }\end{array}$ & Salim A. Fillah & \\
\hline 15 & Sharaf Wahid & $\begin{array}{l}\text { Muhammad } \\
\text { Kamal }\end{array}$ & Pelajaran Kampus \\
\hline 16 & $\begin{array}{l}100 \text { IImuwan } \\
\text { Muslim }\end{array}$ & Qori Ratna & $\begin{array}{l}\text { Menambah } \\
\text { Wawasan tentang } \\
\text { Ilmuwan }\end{array}$ \\
\hline 17 & Udah Putusin Aja! & Felix Siaw & Sesuai kebutuhan \\
\hline 18 & $\begin{array}{l}\text { Saksikan bahwa } \\
\text { Aku Seorang } \\
\text { Muslim }\end{array}$ & Salim A. Fillah & Tugas mentoring \\
\hline 19 & $\begin{array}{l}\text { Jalan Cinta Para } \\
\text { Pejuang }\end{array}$ & Salim A. Fillah & Tugas Mentoring \\
\hline
\end{tabular}

Sumber: Diolah dari Angket Pengumpulan Data Penelitian "Bacaan Keagamaan Aktivis Kampus", Balai Litbang Agama Jakarta, 2015.

Selain buku-buku di atas, bacaan keagamaan yang penting diungkap adalah bahan-bahan yang disampaikan pada kegiatan mentoring. Mentoring adalah suatu kegiatan yang dilaksanakan secara rutin oleh LDK maupun LDF, yang berisi kajian Islam. ${ }^{29}$ Mentoring diyakini bukan hal baru dalam Islam. LSI al-Biruni misalnya merujuk pada Al-Qur'an Surah al-Jumu'ah, ayat 2, yang artinya:

"Dialah yang mengutus seorang Rasul kepada kaum yang buta huruf dari kalangan mereka sendiri, yang membacakan kepada mereka ayat-ayat-Nya, menyucikan (jiwa) mereka dan mengajarkan kepada mereka Kitab dan Hikmah (Sunnah), meskipun sebelumnya mereka benar-benar dalam kesesatan yang nyata" (Q.S. al-Jumu'ah/62: 2).

Rujukan lainnya adalah riwayat Umar bin Khattab r.a. tentang hadis Jibril:

"Ketikakamiduduk-dudukdisisiRasulullah saw. pada suatu hari, tiba-tiba datanglah seseorang laki-laki yang mengenakan baju

${ }^{29}$ Ali Muzakir, “Tipologi Literatur Keagamaan Aktivis Muslim Kampus...”, h. 117-118. yang sangat putih dan berambut sangat hitam, tidak tampak padanya bekas-bekas perjalanan jauh dan tidak ada seorang pun di antara kami yang menenalinya. Hingga kemudian dia duduk di hadapan Nabi, lalu menempelkan kedua lututnya pada lutut Rasulullah, seraya berkata :"Wahai Muhammad, beritahukan aku tentang Islam?" (H.R. Muslim). ${ }^{30}$

Hal yang menarik dalam perkembangan saat ini adalah bahwa materi mentoring tersebut telah banyak di-online-kan (diunggah) sehingga dapat diakses secara terbuka, dan beberapa buku dapat didownload (unduh) secara utuh. Selain itu, materi kajian Islam dalam berbagai pertemuan banyak pula yang dipublikasikan secara online, baik dalam bentuk artikel atau tulisan pendek maupun laporan kegiatan pertemuan dimaksud. Oleh karena itu, mengamati bacaan keagamaan aktivis kampus belum lengkap jika belum disertakan bahan-bahan yang terdapat dalam berbagai situs resmi dari LDK dan LDF-LDF. Fakhruroji menyebut fenomena ini sebagai cyberreligion, ketika agama beraliansi dengan jejaring internet sehingga muncul ruang agama di jagatmaya. Internet, dengan demikian, dapat mengubah ekspresi keagamaan dan wajah agama. ${ }^{31}$

Dalam Web LDK Salim UNJ, yakni http:// salimunj.com, sebagaimana dijelaskan salah seorang pengurusnya, Rizki Kurniawan, dari Prodi Ilmu Agama Islam dan LDF Islamic Center al-Ijtima'i, bahwa bahan bacaan keagaamaan beserta bidang kajiannya dapat

30"“Mentoring", http://fsialbiruni-ftunj.blogspot. co.id/2012/08/mentoring.html. Diakses 07/09/2015.

${ }^{31}$ Moch. Fakhruroji. 2011. Islam Digital, Ekspresi Islam di Internet, Bandung: Sajjad Publishing. 85-87 dan 99. 
dilihat di situs http://salimunj.com. ${ }^{32}$ LDK Salim UNJ secara rutin mempublikasikan kegiatankegiatannya dan materi-materi kajiannya dalam situs tersebut. Bidang kajiann dan materimateri yang disajikannya adalah sebagai berikut:

Tabel 2

Bidang Kajian dan Materi Pembahasan LDK Salim UNJ ${ }^{33}$

\begin{tabular}{|c|c|c|}
\hline No & Bidang Kajian & Materi \\
\hline 1. & Akidah & $\begin{array}{l}\text { Admin http://salimunj.com: Tauhid Asma' wa Shifat, Ma'rifatul Islam, Ahammiyah Syahadatain } \\
\text { (Pentingnya Dua Kalimat Syahadat), Syarat Diterimanya Syahadat, Hal-Hal yang Membatalkan } \\
\text { Dua Kalimat Syahadat, Makna Kata "Ad-Diin", Mari Mengenal Allah, Halawatul Iman (Manisnya } \\
\text { Iman), Mengamalkan Teori Ukhuwah, dan Amal Nyata Adalah Bukti Iman di dalam Dada, } \\
\text { Totalitas Hidup Seorang Muslim (oleh: DR. Ahzami Sami'un Jazuli), Kesempurnaan Islam, Ma'iyyatullah } \\
\text { (Kebersamaan Allah), Membongkar Kesesatan Syi'ah (oleh: Ayu Mega Uswatun Chasanah, Redaksi PDK } \\
\text { Nuraniku UNJ), Mengenal Aliran Sesa[a]t Syiah (oleh: Muhammad Raditya Nugraha, Ketua PDK NURANIKU } \\
\text { 2011), Inilah Hukum Menggambar Wajah Nabi, Pantaskah Iman Digadaikan? (oleh: Irfan Ramadhan, } \\
\text { Redaksi PDK Nuraniku UNJ), Inilah Akibat Yang Ditimbulkan Dari Gambar Wajah Nabi, (oleh Salimunj/ } \\
\text { Fimadani/Ust.Zarkasih Ahmad, Lc.), Sejarah Kelam Valentine Day, Takut Hanya Kepada Allah, Iman dan } \\
\text { Ukhuwah (oleh:Syarifuddin Mustafa, MA.), Mengamalkan Teori Ukhuwah dan Mudik ke Akhirat (oleh: Nufi } \\
\text { Eri Kusumawati)n }\end{array}$ \\
\hline 2. & Al-Qur'an & $\begin{array}{l}\text { Bersiaplah Untuk Bahaya Odoj!!! (oleh: Ratri Indah Cahyani, Jurnalistik Nuraniku UNJ), Menyemaikan al- } \\
\text { Qur'an dalam Kehidupan (oleh: Lisfatul Fatinah Munir, Redaksi PDK NURANIKU UNJ), Ta'riful Qur'an, Hidup } \\
\text { Bersama Al-Quran (oleh: Airell Tuffliado, Ketua Qur'an Institute UNJ, 2012), Al-Qur'an Mendahului Sains } \\
\text { Modern, Al-Qur'an Kitab Hidayah, Tips Jitu Hafal Al-Qur'an, Bacalah Al-Qur'an dengan Tartil (oleh : Syifa } \\
\text { Nurul Nisa), dan Baca Quran Langgam Jawa, Haramkah? (oleh: Ahmad Sarwat, LC., MA) }\end{array}$ \\
\hline 3. & Hadis & $\begin{array}{l}\text { Hadis Arba'in An-Nawawi, Ibu Lebih Berhak atas Kebaikan Anaknya, Hubungan dengan Saudara } \\
\text { yang Masih Musyrik, dan beberapa petikan dari Hadis Arba'in yang telah dipilih, misalnya Hadits Arbain ke-15: } \\
\text { Berkata yang Baik atau Diam dan Hadis Arbain ke-21: Istiqomah }\end{array}$ \\
\hline 4. & Dakwah & $\begin{array}{l}\text { Teladan di Atas Jalan Dakwah dan Problem Iman (oleh: Syaikh Musthafa Masyhur), Taat Kepada Qiyadah } \\
\text { Dakwah (oleh: Ust. Farid Nu'man Hasan), Ruhiyah, Bekal Dalam Berdakwah (oleh: Dr. Attabik Luthfi, MA), } \\
\text { Barisan Dakwah Harus Solid (oleh: DR. Amir Faishol Fath, M.A), Bekal Utama Aktivis Dakwah (oleh: DR. Amir } \\
\text { Faishol Fath, M.A.), Da'i dan Kekuatan Ruhiyah (oleh: Irfanul Arifin), Gairah Cinta dan Kelesuan Ukhuwah } \\
\text { (oleh: Alm. KH. Rahmat Abdullah), Kiat Sukses Dakwah Fardhiyah, Integrasi Politik dan Dakwah (oleh: } \\
\text { Ust. Cahyadi Takariawan), Substansi dan Strategi Dakwah Rasulullah Saw. Periode Madinah, Menjual } \\
\text { Diri Kepada Allah (oleh: Mus'ab Abdurrahman), Berjuang Dengan Ikhlas Abu Ubaidah Al-Jarrah, Orang } \\
\text { Kepercayaan Umat Ini, dan Jadikan Takwa sebagai Senjata (oleh: M Yusron Mufid) }\end{array}$ \\
\hline 5. & Ibadah & $\begin{array}{l}\text { Keajaiban Doa (oleh: Aryo Luhur), Lailatul Qadr (oleh: Nayla Nuha), Agar Ramadhanmu Tak Sia-Sia, } \\
\text { Amalan-Amalan Utama Saat Terjadi Gerhana, dan Mengejar Pahala Idul Adha (oleh: Amrina Anggrarini, } \\
\text { Staf Redaksi PDK Nuraniku) }\end{array}$ \\
\hline 6. & $\begin{array}{l}\text { Pendidikan dan } \\
\text { Moral }\end{array}$ & $\begin{array}{l}\text { Cara Nabi Mendidik Anak Berkebutuhan Khusus, Resume KIU: Generasi Tafaquh Fiddin, } \\
\text { Istimewakan Guru-guru Kita! (oleh: Anis Baswedan), Menjadi Generasi Muda Islam yang Membangun } \\
\text { Peradaban, Revitalisasi Empat Pilar Kebangsaan (oleh: Hj. Herlini Amran, M.A.), Karakterisasi Diri Sejak Dini } \\
\text { Dalam Islam (oleh: Siti Hadianti), Mereka, Tercipta dari Benih Seorang Lelaki dan Lahir dari Rahim } \\
\text { Seorang Perempuan, Bukan dari LGBT (oleh: Tim Jurnalistik PDK NURANIKU UNJ), Pendidikan Karakter } \\
\text { Luqmanul Hakim (Kajian Ust. Bachtiar Nasir -IBF) (oleh: Suryani Achtasuri, Staff Departemen Pendidikan BEM } \\
\text { UNJ, 2014), Pendidikan yang Berbudaya (oleh: Ahmad Fauzi, S.Pd., Direktur Education Watch UNJ, 2011), dan } \\
\text { Memaknai Mahasiswa Sebagai Pilar Perubahan Bangsa (oleh: Roby Tri Wahyudi, Ketua Umum BEM UNJ } \\
\text { 2012) }\end{array}$ \\
\hline 7. & Ekonomi Islam & $\begin{array}{l}\text { Riba Menghancurkan ! (oleh: Atika Aziz,S.Pd.), Stop Riba Sekarang Juga!!! (oleh: Atika Aziz, Humas dan Media } \\
\text { Salim UNJ), Kebangkitan Ekonomi Spiritual sebagai Mainstream Perekonomian Indonesia (oleh: Akmal } \\
\text { Junmiadi, Ketua Umum KAMMI Komisariat UNJ 2011-2012), dan Konsep Uang Dalam Islam (oleh: Drs. Agustianto, } \\
\text { M.Ag.) }\end{array}$ \\
\hline
\end{tabular}

${ }^{32}$ Rizki Kurniawan, Wawancara, 7 September 2015, di Kampus UNJ, Rawamangun Jakarta Timur.

${ }^{33}$ Pembagian bidang ini berdasarkan publikasi dalam http://salimunj.com/s2/category/c82-tsaqafah-islamiyah/. Data tentang bacaan ini merupakan publikasi dalam situs ini sebagai "artikel digital atau online" sehingga tidak ada kelengkapan tempat terbit dan penerbitnya. 


\begin{tabular}{|c|c|c|}
\hline 8. & Keluarga Islami & $\begin{array}{l}\text { Kewajiban Berbakti kepada Orang Tua (oleh: Rindah Jhayanti), Nasihat Pernikahan Untuk Sahabat } \\
\text { yang Sudah atau Akan Menikah, Kedudukan Keluarga dalam Islam (oleh: Syaikh Musthafa Masyhur), } \\
\text { Kondisikan Anak dengan Nuansa Tarbiyah Pelajaran Parenting dari Marathon (oleh: Ramdhani } \\
\text { Purnomo, Humas dan Media LDK SALIM UNJ 2013), Urgensi Pembentukan Keluarga, Karakteristik Baitul } \\
\text { Muslim (Keluarga Islami), dan } 13 \text { Sifat Laki-Laki yang Tidak Disukai Perempuan (Istri) (oleh: DR. Amir } \\
\text { Faishol Fath, M.A.) }\end{array}$ \\
\hline 9. & $\begin{array}{l}\text { Sirah (Nabi, Sahabat } \\
\text { dan Tabi'in) }\end{array}$ & $\begin{array}{l}\text { Sejak Bi'tsah Hingga Hijrah ke Habsy, Sejarah Kelahiran Hingga Kenabian, Beginilah Cara Rasulullah } \\
\text { Menghadapi Fitnah Media (oleh: Ahmad Hidayat, Ketua FSLDK JADEBEK), Saat Bilal Bin Rabah 'Mudik' Ke } \\
\text { Madinah (oleh: Suandri Ansah), Kisah Sahabat Nabi: Sa'id bin Amir Al-Jumahi, Fudhail Bin lyadh dan } \\
\text { Jubah Orang Kaya, Kebahagiaan Memaafkan, Suhail bin Amru-Sang Orator Suku Quraisy (oleh: } \\
\text { Ramdhani Purnomo-Humas dan Media LDK SALIM UNJ), Zubair bin Awwam Salah Satu Tetangga Rasulullah } \\
\text { di Surga (oleh: Muhammad Raditya Nugraha, Ketua Umum NURANIKU UNJ 2011), 10 Sahabat yang Dijamin } \\
\text { Masuk Surga, Fatrah (Masa Kosong dari Kenabian) Yang Gelap Lagi Mengkhawatirkan, dan Kisah } \\
\text { Khalifah Umar bin Khaththab }\end{array}$ \\
\hline 10. & $\begin{array}{l}\text { Tazkiyatun Nafs } \\
\text { (Penyucian Jiwa) }\end{array}$ & $\begin{array}{l}\text { Berlomba Raih Piala Akhirat di Tengah Gema Piala Dunia (oleh: Bella Annisa Asri, Pimpinan Redaksi PDK } \\
\text { NURANIKU UNJ Juli 2014), Bolehkah Menangis? (oleh: Mufti Fadillah, Redaksi PDK NURANIKU UNJ), Nikmatnya } \\
\text { Cemburu (oleh: Mufti Fadilah, Redaksi PDK NURANIKU UNJ), Orang-Orang yang Dido'akan Malaikat (oleh: } \\
\text { Syaikh DR. Fadhl llahi), Menyadari Jiwa dalam Ujian Dakwah (oleh: Airell Tufliado, Mudir Quran Institute 2012), } \\
\text { Macam-macam Hati \& Pembagiannya, Mensana Mensini, Amal Itu Jalan, Bukan Tujuan, Kematian } \\
\text { dan Isti'dad Liyaumirrahil, Madrasah Hati di Bulan Ramadhan (oleh: Irfanul Arifin, Kadept. Humas LDK } \\
\text { SALIM UNJ 2011), Penyakit Syubhat (oleh: Desy Aryani, Kaderisasi LDK SALIM UNJ 2013), Taubat, Duri-Duri yang } \\
\text { Merusak Ukhuwah (oleh: Abu 'Ashim Hisyam bin Abdul Qadir 'Uqdah), dan Pengaruh Dosa dalam Kehidupan }\end{array}$ \\
\hline 11. & Motivasi Islami & $\begin{array}{l}\text { Beginilah Jalan Ini Mengajarkan Kami (Untuk Seluruh Laskar Dakwah LDK-LSO-LDF) (oleh: Trias } \\
\text { Jayanti, Ka. PSDM LSO PDK NURANIKU UNJ), Berjuang Tanpa Henti dengan Janji yang Pasti (oleh: } \\
\text { Hamidatun, LDK Salim UNJ 2012, Peserta International Muslim Student Summit), Man Jadda wa } \\
\text { Jada (oleh: Ahmad Khairudin, Ketua NURANIKU UNJ 2012), dan Menjadi Aktivis Prestatif (oleh: } \\
\text { Aisyah Elia Susanti, S.E, Mantan Aktivis HMJ Manajemen, BEM FE UNJ, Tim Pembela Mahasiswa } \\
\text { (TPM) UNJ, dan NURANIKU UNJ). }\end{array}$ \\
\hline
\end{tabular}

Menurut Hadid Fadila, Ketua LDF Fakultas Bahasa dan Sastra, dalam konteks kehidupan sehari-hari, para aktivis lembaga dakwah atau kelompokstudi keagaman tidak mengkhususkan pada satu bidang kajian saja. Mereka juga dituntut untuk memenuhi kebutuhan bacaan keagamaan yang terkait dengan kebutuhan personal maupun prodi atau fakultas masing-masing. Salah satu contohnyaadalah kebutuhan personal dalam hal pembelajaran, mereka mengadakan kajian kitab Ta'līmul Muta'allim fi Adab al-Ta'allum wa al-Muta'allim. ${ }^{34}$ Demikian juga menurut Hadi al-Hadi, mahasiswa Prodi Bahasa Arab, anggota LDF Fakultas Bahasa dan Sastra. Bacaan keagamaan anggota LDK relatif beragam, biasanya terkait dengan tugas mentoring atau materi yang disampaikan pada saat mentoring.

${ }^{34}$ Hadi Fadila, Wawancara, 11 September 2015, di Kampus UNJ, Rawamangun, Jakarta Timur.
Oleh karena itu, bacaan keagamaannya juga tergantung pada narasumber dalam mentoring. ${ }^{35}$

Salah satu buku yang digunakan dalam mentoring tersebut adalah Amal Jama'i, Gerakan Bersama, karya As-Syaikh Mushthafa Masyhur, yang diterbitkan dalam versi pdf, tanpa disebutkan penerbitnya, tetapi dapat diunduh dari situs http://fsialbiruni-ftunj. blogspot.co.id. Buku lainnya adalah "At-Ṭariq ilal Qulūb, Bagaimana Menyentuh Hati, KiatKiat Memikat Objek Dakwah" karya Abbas As-Siisi, yang ditebitkan oleh www.dakwah. info dalam versi pdf, pada 1416 H/1995 M. Kedua buku ini membahas tentang dakwah dan bagaimana menyentuh hati objek dakwah. Terkait dakwah, menurut AsSyaikh Mushthafa Masyhur dakwah harus dilaksanakan secarajamaah. Ia mendasarkan

${ }^{35}$ Hadi al-Hadi, Wawancara, 7 September 2015, di Kampus UNJ, Rawamangun, Jakarta Timur. 
pandangannya pada Surah Ali Imran, ayat 104, yang artinya: "Dan hendaklah ada di kalangan kamu segolongan umat yang menyeru pada kebaikan, menyuruh pada yang ma'ruf dan mencegah dari yang mungkar, merekalah orangorang yang beruntung." (Q.S. Ali Imran:104). Menurutnya, "dakwah bersama jamaah adalah dakwah yang paling efektif dan sangat bermanfaat bagi Gerakan Islam. Sebaliknya dakwah secara bersendirian akan kurang pengaruhnya dalam usaha menanamkan ajaran Islam pada umat manusia..." ${ }^{36}$

Abbas as-Sīsi mengatakan bahwa "Dakwah jama'iyah (kolektif) mengandalkan ceramah, semangat, dan kemampuan menggugah perasaan. Sedangkan dakwah fardiyah (individu) memiliki karakteristik, cara, dan tahapan-tahapannya sendiri. Ia adalah tahap kedua dari proses interpretasi, penjelasan, studi argumentatif, serta pembuktian dalil. Pada akhirnya, ia merupakan masa panen dan pemetikan buah." ${ }^{37}$ Oleh karena itu, dakwah terhadap individu memerlukan cara yang berbeda dan waktu yang lama. Menurutnya, pemikiran tertentu "dibangun dan dipusatkan pada bacaan, dialog dalam waktu yang sangat panjang, bahkan terkadang perlu muraja'ah (kilas balik)." ${ }_{38}$ Di sinilah posisi bacaan menjadi penting dalam proses dakwah tersebut. Kesinambungan dan perubahan pemikiran dan ideologi, bahkan gerakannya

\footnotetext{
${ }^{36}$ Syaikh Mustafa Masyhur, Amal Jama'i, Gerakan Bersama, versi pdf, h. 2 (diunduh dari http://fsialbiruniftunj.blogspot.co.id/2012/09/download-materisoftwaretarbiyah-kampus.html, pada 2 September 2015).

${ }^{37}$ Abbas As-Sīsi, At-Ṭariq ila al-Qulūb, Bagaimana Menyentuh Hati, Kiat-Kiat Memikat Objek Dakwah", www. dakwah.info dalam versi pdf, 1416 H/1995 M., h. 125.

${ }^{38} \mathrm{Abbas}$ As-Siisi, At-Thariq ilal Qulub, Bagaimana Menyentuh Hati..., h. 125.
}

dapat dilacak melalui bahan bacaan tersebut. $^{39}$

Selain bacaan di atas, terdapat banyak buku dan materi bacaan yang dapat diakses dan diunduh melalui jejaring internet, khususnya pada situs http://fsialbiruniftunj.blogspot.co.id/2012/09/downloadmaterisoftware-tarbiyah-kampus.html. Bahan bacaan tersebut antara lain Adab Pergaulan menurut Al-Qur'an dan Sunnah, karya Rokiah Ahmad; Fatwa Kontemporer, karya Yusuf Qardhawi; Analisis Instan Problematika Dakwah Kampus, karya Ridwansyah; Dakwah Fardiah, karya Mustafa Masyhur; Dari Gerakan ke Negara, karya Anis Matta; Fi Zilāl al-Qur'ān: Ayat-ayat Pilihan, karya Sayyid Qutb; Generasi Pemuda dan Perubahan, karya Fathi Yakan, Ma'ālim fī Aț-Țāriq, karya Sayyid Qutb; Risalah Manajemen Dakwah Kampus, disusun oleh Gamais ITB (Bandung); Tarbiyah Islam \& Madrasah Hasan Al-Banna, karya Yusuf Qardhawi, dan lain-lain (isi ringkas bahan bacaan keagamaan dari situs ini, lihat lampiran)

Dalam situs yang sama juga dapat didownload Mp3 Al-Qur'an Mushaf Madinah yang sudah dimodifikasi per halaman. Ada sekitar 604 halaman dalam mushaf tersebut sehingga file-file MP3 tersebut berjumlah 605 file mp3 ditambah dengan satu file mp3 yang berisi do'a khatmil-Qur'an. “Tujuan editing mp3 ini adalah untuk memudahkan kita semua bertilawah sambil membaca mushaf dan menghafalnya atau memuroja'ahnya. Anda boleh mendistribusikannya kembali." Demikian penjelasan dari admin Web FSI AlBiruni. ${ }^{40}$

${ }^{39}$ Ali Akbar, “Berjuang di Jalan Dakwah..., h. 102.

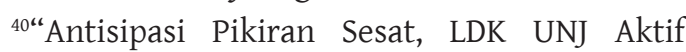
Gelar Kajian”, berita dalam https://www.islampos. 
Adapun beberapa materi dalam bentuk artikel dan laporan kegiatan di antaranya materi kajian rutin mingguan LDK Salim UNJ yang dilaksanakan setiap hari Selasa sore. Demikian juga dengan kegiatan kajian bulanannya yang disebut Studi Kritis Islam (SKI). Misalnya pada 11 September 2013, kajian rutin mingguan dilaksanakan di pelataran Masjid Nurul Irfan karena sasarannya adalah Mahasiswa UNJ secara umum dengan materi pemikiran Islam. Menurut Ketua LDK Salim saat itu, Ahmad Hidayat, "Kajian pemikiran Islam memang lebih diminati dibandingkan dengan kajiankajian keislaman lainnya." Materinya adalah tentang pemikiran yang dipandang sesat seperti isu-isu multikulturalisme, pluralisme agama, dan persoalan aliranaliran sesat. "Dengan visi dan misi sebagai garda terdepan dalam melindungi akidah dan menjadi sarana mengenal Islam lebih baik, perjuangan LDK Salim ini tidak lantas berjalan tanpa hambatan." (Eza/Islampos)

Pada tahun 2015, tema "Islam Nusantara" juga menjadi sorotan LDK Salim UNJ. Pada 26 Juli 2015, situs sharia.co.id memberitakan hal ini sebagai berikut: "Ketua Lembaga Dakwah Kampus (LDK) Salim Universitas Negeri Jakarta (UNJ), Zarqony Alwy Ahmad menyatakan bahwa "Islam Nusantara," istilah yang sedang marak digencarkan oleh kalangan kaum liberal di Indonesia merupakan konsep yang dapat memecah belah kaum Muslimin. Istilah ini pun

com/antisipasi-pemikiran-sesat-ldk-unj-aktif-gelarkajian-77871/, published Jumat, 13 Zulkaedah 1436 / 28 Agustus 2015. Diakses 02 September 2015. Korespondensi dapat dilakukan melalui e-mail: fsi. albiruni.unj@gmail.com. dinilai kental dengan upaya "deislamisasi Indonesia." ${ }_{41}$

Menurut Zarqony Alwy Ahmad, "hal tersebut adalah sebuah bentuk untuk membuat orang-orang Muslim menjauh dari așālah Islam yang ada, sehingga membuat seorang muslim semakin jauh dengan akar Islamnya. Kalau boleh dikatakan ini adalah bentuk 'deislamisasi Indonesia”.' Oleh karena itu, menurutnya, "istilah 'Islam Nusantara' harus segera dihilangkan, selain itu berbagai pihak dihimbau agar segera mengklarifikasi terkait konsep "Islam Nusantara" tersebut, karena dinilai akan merusak kondisi umat Muslim di negeri ini terkait dengan keislamannya. Islam hanya satu, yaitu Islam yang diturunkan oleh Allah dan dibawa oleh Nabi Muhammad saw., bukan Islam yang lain berdasarkan dengan budaya dan kekhasan suatu daerah atau negara. Justru Islam datang untuk memperbaiki budaya dan juga ciri khas dari suatu daerah tersebut. Dan setiap yang diajarkan oleh Islam itulah yang terbaik." Jadi, menurutnya, Islam Nusantara berpotensi memecah umat Islam dan juga dapat merusak pemahaman seorang Muslim tentang Islam itu sendiri. ${ }^{42}$

LDK Salim UNJ telah mempublikasikan materi-materi keagamaan melalui web salimunj.com. Dalam salah satu kegiatannya yang disebut Kajian Islam Terpadu, pada 26 Februari 2015, dapat terlihat pandangan keislaman yang dibahasnya. Dengan judul kajian "Generasi Tafaquh Fid-din" disajikan

${ }^{41}$ Ilham, "Ketua LDK Salim UNJ: Istilah Islam Nusantara Memecah Belah Kaum Muslimin," alam http://www.sharia.co.id/ketua-ldk-salim-unj-istilahislam-nusantara-memecah-belah-kaum-muslimin. html, 28 Agustus 2015. Diakses 05/09/2017.

${ }^{42}$ Ilham, "Ketua LDK Salim UNJ: Istilah Islam Nusantara Memecah Belah Kaum Muslimin" 
materi tentang Islam, iman, dan ihsan. Dalam kajian tersebut dijelaskan bahwa "Islam adalah ilmu. Bicara Islam tak bisa lepas dari ilmu. Jangan mengaku sebagai umat Islam jika kita mengabaikan ilmu. Generasi tafaquh fiddin: generasi yang memahami Islam secara mendalam. Fiqh: paham yang sangat mendalam. Bagi muslim menjadi tafaquh fid-din hukumnya fardu kifayah, jika dalam satu masyarakat tidak terdapat seorang yang fāqih agama maka seluruh individu mendapatkan dosanya." (salimunj.com)

Beberapa hal terkait ilmu dijelaskan dalam kajian tersebut, yaitu bahwa berdasarkan sabda Nabi, para pencari ilmu dikelompokkan menjadi empat, yaitu: 1) orang yang 'ālim, orang yang berilmu, 2) muta'allim, yang menuntu ilmu, 3) mustami'an (mendengar), dan 4) muhibban (pecinta ilmu). Sedangkan syarat mencari ilmu, mereka merujuk pada nasiahat Ali bin Abi Talib, yaitu: “1) żakā’un, kecerdasan, Allah memberikan akal maka pergunakan untuk selali berpikir; 2) hirșun, tidak pernah puas dengan ilmu yg sudah didapat; 3) iștibār, sabar, atau ijtihādun, sungguh-sungguh; 4) bulgah atau dirhamun, maksudnya adalah pengorbanan finansial; 4) irsyādu ustāż atau șuhbatu ustāż, yakni bimbingan atau bersahabat dengan guru yang paham tentang ilmu; dan 6) țūlu zamān, waktu yang lama. ${ }^{43}$

Tema menarik adalah "Motivasi Islami". Tema ini memberikan semangat kepada para aktivis LDK karena sesama mereka terus saling mengingatkan dan mendorong kamajuan. Aisyah Elia Susanti, S.E., Mantan

\footnotetext{
${ }^{43}$ Fadhilah Chaniago, "Resume KIU: Generasi Tafaquh Fiddin", dalam http://salimunj.com/ s2/2015/02/26/resume-kiu-generasi-tafaquh-fiddin/, February 26th, 2015. Diakses 5 September 2015.
}

Aktivis HMJ Manajemen, BEM FE UNJ, Tim Pembela Mahasiswa (TPM) UNJ, dan Nuraniku UNJ, membahas materi “Menjadi Aktivis Prestatif". Ia mengutip ayat Al-Qur'an, yang artinya: “... Allah akan mengangkat derajat orang-orang yang beriman di antaramu dan orang-orang yang diberi ilmu pengetahuan beberapa derajat. Dan Allah Mahateliti apa yang kamu kerjakan." (Q.S. Al-Mujādilah/58: 11). Kemudian ia menjelaskan,

"Perubahan yang dikehendaki dakwah demi tegaknya peradaban Islam menembus wilayah individu-individu, masyarakat, dan negara sampai terbangunnya peradaban Islam di muka bumi, selain membutuhkan waktu yang sangat panjang hingga mampu melampaui umur individu bahkan umur sebuah generasi, juga membutuhkan sumber daya manusia di semua lapisan masyarakat, di semua sektor kehidupan dengan semua jenis keahlian dan potensi, juga dibutuhkan SDM yang qawiy (kuat) secara fisik, komitmen dalam dakwah dan jamaah, serta memiliki energi serta semangat ruhiyah yang tinggi." ${ }_{44}$

Aisyah Elia Susanti sependapat dengan Anis Matta, dalam hal tahapan dakwah yang harus dilakukan untuk membangun peradabatan. Dengan mengutip buku Anis Matta, 'Menikmati Indahnya Demokrasi', ia menyajikan empat langkah berikut:

Pertama, membangun kekuatan dan organisasi yang solid sebagai kekuatan yang akan menggerakan roda dakwah, inilah yang disebut mihwar tanzīmī, dan kita sudah melewati masa ini.

\footnotetext{
${ }^{44}$ Aisyah Elia Susanti, "Menjadi Aktivis Prestatif", http://salimunj.com/s2/2012/09/05/menjadi-aktivisprestatif/, upload September 5th, 2012, by BangSalim. Diakses 2 September 2015.
} 
Kedua, membangun basis sosial yang luas dan merata sebagai kekuatan pendukung dakwah. Kaidah dakwah mengatakan 'yakhtalițūn yatamayazūn' berbaur dan mewarnai, inilah yang disebut mihwar sya'bi, dan kita pun telah melewati era jahriyah jamahiriyah ini. Kalau basis organisasi (tanzimī) berorientasi pada kualitas maka basis sya'bi berorientasi pada kuantitas.

Ketiga, membangun berbagai institusi/ lembaga/wajihah untuk mewadahi pekerjaan-pekerjaan dakwah di seluruh sektor kehidupan dan seluruh segmen masyarakat. Di tataran kampus misalnya, ada namanya Lembaga Dakwah Kampus (LDK) atau Lembaga Media Islami untuk mewadahi aktivitas kerohanian mahasiswa, ada lembaga siyasi: BEM, HIMA, pergerakan, partai untuk mewadahi kegiatan-kegiatan politik mahasiswa, ada juga wajihah akademik: Fossei, Forsima, MITI, ESC, LKM, dll untuk mewadahi kegiatankegiatan akademik mahasiswa. Dan inilah yang dinamakan mihwar muasasi, dan dakwah kita sedang berada dalam fase ini sekarang. Kalau dalam tahap sya'bi, kader dakwah disebar ke masyarakat untuk 'tampil cantik' di hadapan masyarakat..., maka dalam tahap muasasi kader disebar ke seluruh institusi (wajihah kalau istilah di kampus) yang ada. Dengan begitu, terbentuklah jaringan aktivis dakwah di seluruh institusi/wajihah yang strategis, sehingga setiap institusi selaras, dan massif dalam visi, misi dan tujuan yang sama, yakni membangun kehidupan bernegara dan masyarakat kampus yang lebih Islami.

Keempat, aktivitas dakwah ini sampai pada tingkatan institusi negara, inilah yang disebut mihwar dauli. Namun kaidah yang harus dipahami pula oleh aktivis dakwah adalah bahwa negara: partai, pergerakan, penguasaan lembaga eksekutif, legislatif, dan yudikatif atau atau kalau dalam tataran kampus: BEM, LDK, Himpunan, bahkan menjadi seorang akademisi di kampus sekalipun bukanlah tujuan akhir. Lembagalembaga itu hanyalah wasilah (sarana). Jika untukmencapaitujuanakhiryaknitegaknya dinullāh di muka bumi ini membutuhkan penguasaan wașilah-wașilah tersebut, maka penguasaan wașilah atau masuknya kader dakwah ke dalam wașilah- wașilah yang ada, menjadi suatu kewajiban, kaidah fikih menjelaskan mā lā yatimmu al-wājibu illā bihi fahuwa wājib (sesuatu yang tidak sempurna bagi suatu kewajiban kecuali dengannya, maka ia menjadi wajib). ${ }^{45}$

Bacaan keagamaan sebagaimana diuraikan di atas tidak terbatas pada buku yang dimiliki dan dibaca oleh aktivis kampus semata, tetapi juga bacaan-bacaan lainnya. Buku dalam bentuk digital termasuk bagian dari rujukan mereka, dan juga bacaanbacaan digital lainnya, baik artikel maupun reportasi kegiatan yang dipublikasikan melalui situs-situs atau web-web LDK maupun LDF.

\section{Ideologi dan Transmisi Bacaan Keagamaan}

Mengidentifikasi ideologi suatu kelompok berdasarkan bahan bacaan bukanlah sesuatu yang mudah walaupun mungkin dapat dilakukan. Salah satu indikator yang dapat dijadikan dasar untuk menentukannya adalah dengan memahami konsep kunci dari kelompok yang dimaksud. Indikator lainnya adalah dasar aktivitas atau pergerakannya dalam menjalankan konsep kunci tersebut. Dalam konteks melihat ideologi LKD di UNJ, dapat ditemukan salah satu konsep kunci mereka, yakni pemahaman mereka tentang Islam. Konsep

\footnotetext{
${ }^{45}$ Aisyah Elia Susanti, "Menjadi Aktivis Prestatif".
} 
"Islam" bagi aktivis LDK UNJ didasarkan pada firman Allah dalam Surah Ali Imran ayat 19: Sesungguhnya agama yang diridai di sisi Allah hanyalah Islam, tiada berselisih orangorang yang telah diberi Al-Kitab kecuali sesudah datang pengetahuan kepada mereka karena kedengkian (yang ada) di antara mereka, barang siapa yang kafir dengan ayat-ayat Allah maka sesungguhnya Allah maha cepat hisabnya" (Q.S. Ali Imran/3: 19), dan ayat 85: "Barang siapa mencari agama lain selain agama Islam, maka sekali-kali tidaklah akan diterima (agama itu)." (Q.S. Ali Imran/3: 85) ${ }^{46}$

Kedua ayat ini dijadikan landasan akidah mereka, yang bisa saja dipandang sebagai dasar ideologi jika dilihat secara sosiologis. Berdasarkan kedua ayat ini, Islam dijelaskan sebagai berikut: a). Al-Islām Al-Wajh, Islam sebagai "menundukkan wajah" kepada Allah; b). Al-Istislām, Islam sebagai "berserah diri" kepada Allah; c). As-Salām, Islam sebagai "keselamatan," menyelamatkan diri dari jalan yang gelap gulita ke jalan yang penuh cahaya kebenaran; d). As-Salāmah, Islam sebagai "suci bersih," baik secara fisik maupun ruhaninya, dan e). As-Silmi, Islam sebagai "perdamaian" bagi seluruh umat. Adapun makna Islam secara istilah, mereka merujuk pada hadis Nabi Muhammad saw, yang berarti: Islam adalah bersaksi tidak ada Tuhan melainkan Allah, Muhammad adalah utusanNya, mendirikan sholat, menunaikan zakat, shaum di bulan Ramadhan dan haji bagi yang mampu melaksanakannya." ${ }^{47}$ Dalam pandangan mereka, Islam memiliki

\footnotetext{
46"Ma'rifatul Islam", http://salimunj.com/ s2/2012/06/22/marifatul-islam/, June 22nd, 2012, BangSalim, "Bidang Akidah". Dikases 5 September 2015.

${ }^{47 " M a ' r i f a t u l \quad I s l a m ", \quad h t t p: / / s a l i m u n j . c o m / ~}$
}

banyak keistimewaan dari karakteristik yang menjadikannya tetap tinggi dan tidak tertandingi oleh agama apapun. Keistimewaan dan karakteristik Islam tersebut antara lain:

Rabbāniyyah, Islam memiliki karakteristik Rabbāniyyah yang secara makna berarti berhubungan dengan Allah Swt. secara langsung dan dipredikatkan kepada manusia dalam bentuk mengetahui agama-Nya dan mengajarkan KitabNya. Yang dimaksud Rabbāniyyah dalam dua hal, yaitu Rabbāniyyah Al-Gāyah walWijhah dan Rabbāniyyah Al-Mașdar walMinhaj. Rabbāniyyah Al-Gāyah wal-Wijhah atau rabbāniyyah dalam orientasi dan tujuan, bahwa Islam menjadikan tujuan akhirnya, dan sasaran jangka panjangnya adalah agar terjadi hubungan baik dengan Rabbnya. Rabbāniyyah al-Mașdar wal-Minhaj, maksudnya adalah bahwa dalam mencapai tujuan dan sasarannya, Islam merupakan manhaj (kurikulum) Rabbāni yang murni karena bersumber dari Allah yang diturunkan kepada Rasulullah Muhammad Saw. yang tidak sedikit pun ada campur tangan dan rekayasa manusia, "dan tiadalah yang diucapkannya itu (Al-Qur'an) menurut kemauan hawa nafsunya" (Q.S. An-Najm: 3)

Insāniyyah, Karakteristik lain yang dimiliki oleh Islam adalah insāniyyah. Maksudnya adalah Islam memberikan ruang luas kepada manusia dalam berijtihad juga dalam berikhtiar. Selain itu, Islam sangat mengajarkan prinsip persamaan hukum di antara manusia. Di dalam Al-Qur'an, yang membedakan manusia satu dengan yang lainnya hanyalah ketakwaannya di hadapan Rabbnya. Hal lain yang menjadi keistimewaan Islam tidak jumud atau 
stagnan (tetap). Namun sebaliknya sesuai dengan perkembangan manusia.

Syumūilyyah (menyeluruh), Islam adalah agama yang tidak terhenti hanya pada satu masa tertentu saja, tetapi Islam meliputi semua zaman. Tidak seperti zaman terdahulu yang para nabi hanya diutus untuk satu umat saja. Namun Muhammad Rasulullah Saw. telah datang penyempurna agama sebelumnya. "Dan tidaklah Kami mengutus kamu melainkan untuk menjadi rahmat bagi seluruh alam" (Q.S. Al-Anbiya': 107). Islam juga menyeluruh dalam semua fase kehidupan manusia. Dari mulai fase kehidupan lahirnya seorang anak hingga masa tua. Tidak diragukan lagi keutuhan petunjuk dalam setiap aspek kehidupan juga diatur dalam Islam. Tidak ada satu aspek pun yang tidak diperhatikan oleh Islam. Kesempurnaan Islamtelah digambarkan oleh seorang ulama Mesir dalam perkataannya "Islam adalah akidah dan ibadah, negara dan kewarganegaraan, toleransi dan kekuatan, perubahan dan perundang-undangan."

Wasațiyyah (pertengahan), Islam sangat memberikan porsi yang seimbang antara akal, jasad, dan ruhiyah. Antara akhirat dan duniawi, antara kebutuhan individu dan jamaah (sosial), juga kemuliaan dan penghargaan yang selalu Allah peruntukkan bagi setiap hamba-Nya yang Muslim. Sekecil apapun kebaikan yang ia lakukan akan mendapat balasan setimpal, juga sebaliknya jika ia melakukan keburukan meskipun hanya sebesar atom maka akan ada balasannya. Sebagaimana sabda Rasul Saw, "Bahwa dalam setiap sendi tulang rusuk anak Adam terdapat potensi sedekah, senyum adalah sedekah, setiap kalimat tasbih sedekah dan menyingkirkan duri dari jalanan sedekah, juga langkah kita menuju salat dihitung kebaikan."
Firman Allah swt.: "Allah menghendaki dari kalian semua kemudahan dan sebaliknya Allah tidak menghendaki dari kalian kesulitan." (Q.S. Al-Baqarah: 185). ${ }^{48}$

Selanjutnya, hal terpenting dalam berislam, menurut mereka, adalah bahwa Islam tidak hanya rakaat-rakaat dalam salat, ucapan-ucapan atau kalimat doa, apalagi hanya sekadar identitas. Mereka melihat fenomena kejahilan umat Islam terhadap ajarannya sendiri yang diakibatkan oleh gencarnya propaganda musuh-musuh Islam yang melecehkan Islam sehingga terjadilah stigmatisasi terhadap Islam dan syariatnya. Umat Islam yang taat dipandang sebagai ekstrimis, atau fundamentaslis, bahkan tidak kurang ironinya, mereka disebut teroris. ${ }^{49}$ Oleh karena itu, mereka menyuarakan,

"Islam harus terpatri dalam seluruh pemikiran kita, tidak berargumen kecuali dengan Islam, tidak beride melainkan dari sumber Islam. Begitu pula dalam setiap detak jantung kita dan aliran darah kita Islam selalu mengikuti dan tetap mengikuti. Betapa mulianya seorang muslim yang telah menyempurnakan dirinya dengan menjadikan Islam sebagai jalan hidupnya. Sehingga tercatatlah pejuang-pejuang Islam yang berani menentang pemerintahan yang zalim dengan menyerahkan jiwa dan ragannya." 50

\footnotetext{
48"Ma'rifatul Islam", http://salimunj.com/ s2/2012/06/22/marifatul-islam/.

${ }^{49}$ Arif Gunawan Santoso, "Strategi Mobilisasi Sumber Daya Fundamentalisme Islam: Studi Hisbut Tahrir Indonesia”, Dialog, Vol. 38 (2) 2015, h. 223-224. (221-236)

${ }^{50}$ Disarikan dari Learning Center LDK UNJ, Buku Panduan Mentoring, (Jakarta: LDK UNJ, 2010), lihat "Ma'rifatul Islam", http://salimunj.com/s2/2012/06/22/ marifatul-islam/.
} 
Dalam konteks perjuangan melawan kezaliman, mereka menyebut salah seorang pejuang Islam dari Mesir, yaitu Sayyid Qutb. Ia dipuji karena telah berani menantang pemerintah Mesir yang zalim pada masanya, dan relah memilih mati di tiang gantungan daripada harus bekerjasama dengan penguasa yang zalim. Katakatanya dikutip, "lebih baik saya mati ditiang gantungan daripada hidup dalam keberpihakan dengan pemerintah yang dzalim." Demikian juga ikrar lima semboyan prinsip Islam yang dikumandangkannya, didengungkan kembai, yaitu: "Allah tujuan kami... Rasulullah pemimpin (teladan) kami... Al-Qur'an pedoman (undang-undang) kami... Jihad jalan hidup kami... Syahid (mati) di jalan Allah cita-cita kami tertinggi." ${ }^{51}$

Indikator kedua dari ideologi adalah dari gerakannya. Dalam lingkungan LDK, termasuk LDK Salim UNJ, pembinaan anggota disebut dengan istilah tarbiyah. Tarbiyah sendiri berasal dari bahasa Arab yang berarti pendidikan atau pembinaan. Dalam konteks aktivitas dakwah di kampus, tarbiyah telah diartikan sebagai pembinaan. Salah satu rujukan dalam kegiatan ini adalah buku yang berjudul "Tarbiyah Dzatiyah" karya Abdullah bin Abdul Aziz al-Aidan, yang diterbitkan oleh Kartor Kerjasama Dakwah, Bimbingan dan Penyuluhan untuk Warga Negara Asing di Syifa, Riyadh, Kerajaan Saudi Arabia (KSA). Dalam buku ini, "Tarbiyah Dzatiyah" diartikan sebagai sejumlah

${ }^{51}$ Umar al-Tilmisani. 2008. Hasan al-Banna Sang Inspirator, Penerjemah: Arya Noor Amarsyah, Jakarta: Kuwais International, h. 80-84. Versi pdf disebarluaskan melalui portal Islam: http://www. Kaunee.com. Lihat juga Learning Center LDK UNJ, Buku Panduan Mentoring, dan "Ma'rifatul Islam", http:// salimunj.com/s2/2012/06/22/marifatul-islam/. metode tarbiyah atau pembinaan yang diterapkan seorang Muslim atau Muslimah, untuk dirinya, dalam rangka membentuk kepribadian Islami yang paripurna dalam berbagai segi, yakni ilmu, iman, akhlak, sosial dan sebagainya. Selain itu juga dimaksudkan agar derajatnya semakin meningkat ke tingkat kesempurnaan sebagai manusia. Dengan istilah lain, "Tarbiyah Dzatiyah" didefinisikan sebagai pembinaan seseorang terhadap dirinya sendiri oleh dirinya sendiri, dengan berbagai macam metode dan dalam berbagai aspeknya. Dengan demikian, pengertian "Tarbiyah Dzatiyah" sama dengan Tarbiyah Jama'iyah atau Pembinaan Kolektif, yang berarti "forumforum umum yang dikerjakan seseorang atau yang digeluti bersama orang lain atau ia tertarbiyah (terbina) di dalamnya bersama mereka, seperti di masjid, keluarga, sekolah, media informasi, persahabatan, rihlah (tour), kunjungan dan berbagai kegiatan dan program lainnya." 52

Dalam buku Tarbiyah Dzatiyah, Abdullah bin Abdul Aziz al-Aidan menjelaskan tujuh sarananya, yaitu: 1) Muhasabah, 2) Taubat dari dosa, 3) Mencari ilmu dan memperluas wawasan, 4) mengerjakan amalan-amalan iman, 5) memperhatikan aspek akhlak (moral), 6) Terlibat dalam aktivitas dakwah, dan 7) Mujahadah (jihad)..$^{53}$

Buku lain adalah Untukmu Kader Dakwah, karya K.H. Rahmat Abdullah. Ada 11 tema dalam buku ini, yaitu: 1). Do'a pada saat

${ }^{52}$ Abdullah bin Abdul Aziz al-Aidan, Tarbiyah Dzatiyah, Penerjemah Fadhli Bahri, Lc. (Riyadh: Kartor Kerjasama Dakwah, Bimbingan dan Penyuluhan untuk Warga Negara Asing di Syifa, 1425 H/2004 M), h. 4 .

${ }^{53}$ Abdullah bin Abdul Aziz al-Aidan, Tarbiyah Dzatiyah, h. 17-64. 
Deklarasi Partai Keadilan, 2). Cahaya di Wajah Ummat, 3). Kedunguan Kasta vs Komitmen Perjuangan, 4). Cermin Diri, 5). Kutbah 'Iedul Adha 1421 H, 6). Militansi, 7). Buah Mengimani Hari Akhir, 8). Kerendahan Hati dan Kepekaan Sosial, 9). Gairah Cinta dan Kelesuan Ukhuwwah, 10). Bulan Ramadlan: Stasiun Besar Musafir Iman, dan 11). Shalawat Atas Nabi saw. Terkait perkembangan dakwah, menurutnya, bahwa "Dakwah berkembang di tangan orangorang yang memiliki militansi, semangat juang yang tak pernah pudar. Ajaran yang merekabawa bertahan melebihi usia mereka. Boleh jadi usia para mujahid pembawa misi dakwah tersebut tidak panjang, tetapi citacita, semangat dan ajaran yang mereka bawa tetap hidup sepeninggal mereka." ${ }^{4}$

Kemudian yang cukup terenal adalah Sayyid Qutb, dengan bukunya Petunjuk Sepanjang Jalan. Dalam buku ini dijelaskan bagaimana kebangkitan Islam dapat dimulai? Sayyid Qutb menjawab, "Mesti ada satu golongan pelopor atau "kader" yang menghayati cita-cita ini, dan meneruskan kegiatannya dengan cara menerobos ke dalam alam jahiliyah yang sedang berpengaruh di seluruh permukaan bumi ini dengan memakai dua kaedah: iaitu kaedah memisahkan diri dan kaedah membuat hubungan di bidang lain pula dengan pihak jahiliyah itu." ${ }^{55}$

${ }^{54}$ K.H. Rahmat Abdullah, Untukmu Kader Dakwah, versi pdf yang di-upload atau diunggah $h t t p: / / h d n . e d u$. $m s$, h. 28.

${ }^{55}$ Syed Qutb, Petunjuk Sepanjang Jalan (versi pdf), h. 8. Diunduh dari http://blog.uny.ac.id/mohkhairudin/ files/2012/02/Petunjuk-Sepanjang-Jalan-Sayyid-QuthbEdisi-Indonesia.pdf (dalam teks tulisan ini, Syed Qutb ditulis Sayyid Qutb).
Beberapa butir pemikiran dan contoh dari bacaan-bacaan di atas dapat dengan jelas terlihat bahwa transmisi pemikiran keagamaan dapat dilakukan melalui media tulis, bacaan atau buku. Sedangkan kecenderungannya sementara dapat dikatakan bahwa LDK Salim UNJ, meskipun tidak secara formal ada bukti afiliasi, secara pemikiran dapat diasosiasikan pada pemikiran Partai Keadilah Sejahtera (PKS) dan gerakan yang Sayyid Qutb, yakni Ikhwanul Muslimin. Perkembangan IM saat ini tentu berbeda dengan pada masa Presiden Gamal Abden Naseer ketika Sayyid Qutb masih hidup. Akan tetapi, dengan adanya keberlangsungan pemikirannya melalui buku ini dapat dikatakan bahwa semangatnya sama.

\section{PENUTUP}

Dari data tentang judul-judul buku, materi mentoring, buku rujukan, dan bahan bacaan yang dipublikasikan dalam beberapa situs LDK dan LDF-LDF di kampus UNJ, bahwa bacaan keagamaan di kalangan aktivis kampus UNJ, setidaknya terdiri atas dua ketegori besar, yaitu: Pertama, bacaan keagamaan untuk kebutuhan pengayaan dan peningkatan wawasan keislaman dan kebutuhan personal; dan kedua, bacaan keagamaan yang terkait kecenderungan organisasi atau kelompok, dalam hal ini adalah LDK, termasuk LDF-LDF yang berada di kamus UNJ.

Dari segi bidang kajiannya, LDK Salim UNJ telah mengelompokkannya menjadi 11 kelompok ditambah satu bagian yang khusus wanita. Tentang riwayah sahabat dalam bidang Sirah, walaupun temanya sama, dalam konten rubrik kewanitaan disebut 
"shahabiyah" (sahabat perempuan) dan ada juga tentang busana. Bidang kajian bacaan keagamaan tersebut adalah Akidah, AlQur'an, Hadis, Dakwah, Ibadah, Pendidikan dan Moral, Ekonomi Islam, Keluarga Islami, Sirah (Nabi, Sahabat dan Tabi'in), Tazkiyatun Nafs (Penyucian Jiwa), dan Motivasi Islami.

Dalam membangun jaringan dan kekuatan, antara lain seperti yang mereka kutip dari Anis Matta, dilakukan dengan empat langkah, yaitu: 1) membangun kekuatan dan organisasi yang solid sebagai kekuatan yang akan menggerakan roda dakwah, inilah yang disebut mihwar tanzìmī; 2) membangun basis sosial yang luas dan merata sebagai kekuatan pendukung dakwah, yang disebut mihwar sya'bi; 3) membangun berbagai institusi/lembaga/ wajihah untuk mewadahi pekerjaanpekerjaan dakwah di seluruh sektor kehidupan dan seluruh segmen masyarakat. Tahap ini disebut mihwar mu'asasī, yang salah satu sasarannya adalah Lembaga Dakwah Kampus (LDK); dan 4) aktivitas dakwah sampai pada tingkatan institusi negara, yang dinamakan mihwar dauli. BEM, LDK, dan Himpunan, atau individu akademisi di kampus, bukan sebagai tujuan tetapi sebagai wașilah atau sarana, yang dipandang wajib untuk menegakkan dinullāh atau agama Allah, yakni Islam.

Meskipun bukan muara dari segala bacaan keagamaan bagi aktivis kampus UNJ, lima prinsip Islam dalam mentoring LDK yang diambil dari Sayyid Qutb dapat menjadi salah satu titik sambung antara gagasan LDK dengan Ikhwanul Muslimin (IM). Kelima ikrar tersebut adalah Allah tujuan kami, Rasulullah pemimpin (teladan) kami, Al-Qur'an pedoman (undang-undang) kami, Jihad jalan hidup kami, syahid (mati) di jalan Allah cita- cita kami tertinggi. Dengan demikian, gagasan dan pemikirannya dapat dikatakan memiliki geneologi yang sampai kepada Sayyid Qutb atau IM, antara lain melalui PKS dan alumnialumni LKD yang masih aktif menjadi narasumber dalam kegiatan-kegiatan LDK, baik mentoring, diskusi, seminar, maupun kegiatan lainnya.[] wallahu a'lam

\section{UCAPAN TERIMA KASIH}

Penulis mengucapkan terima kasih kepada banyak pihak yang telah memberikan kesempatan kepada dan membantu penulis dalam menyelesaikan tulisan ini. Pertama, kepala Kepala Balai Litbang Agama Jakarta (BLAJ) yang telah menugaskan penulis untuk melakukan penelitian tentang "Bacaan Keagamaan Aktivis Kampus”, dalam hal ini di Universitas Negeri Jakarta (UNJ), pada tahun 2015. Kedua, kepada para informan antara lain Bagian Humas UNJ, beberapa pengurus Lembaga Dakwah Kampus (LDK) UNJ maupun Lembaga Dakwah Fakultas (LDF) di beberapa fakultas di lingkungan UNJ, yang telah membantu memberikan informasi dan data terkait pokok pembahasan dalam penelitian ini. Selanjutnya, kepada para narasumber dan para sahabat sekalian yang telah memberikan saran dan kritik dalam menyempurnakan laporan ini. Tak lupa pula kepada Redaksi Jurnal Edukasi dan Mitra Bestari yang telah memberikan saran perbaikan sehingga tulisan ini dapat dimuat di Jurnal Edukasi. Semoga Allah Swt. memberikan balasan yang lebih baik kepada mereka, juga senantiasa dalam kesuksesan dan keberkahan. Amin... 


\section{DAFTAR PUSTAKA}

Abdullah, K.H. Rahmat. (t.t): Untukmu Kader Dakwah, versi pdf yang di-upload atau diunggah http://hdn.edu.ms. Diakses 02 September 2015.

al-Aidan, Abdullah bin Abdul Aziz. (1425 H/2004 M): Tarbiyah Dzatiyah. Penerjemah Fadhli Bahri, Lc. Riyadh; Kartor Kerjasama Dakwah, Bimbingan dan Penyuluhan untuk Warga Negara Asing di Syifa.

Akbar, Ali. (2007): "Berjuang di Jalan Dakwah, Kajian Pemetaan Buku-Buku Keagamaan di Universitas Negeri Yogyakarta", Jurnal Lektur Keagamaan, Vol. 5 (1): 84-104.

bin Nabi, Malik. (1994): Membangun Dunia Baru Islam (Terj. Afif Muhammad dan Abdul Adhiem, dari Syuruth alNahdhah). Bandung; Mizan.

Fakhruroji, Moch. (2011): Islam Digital, Ekspresi Islam di Internet. Bandung; Sajjad Publishing.

Keputusan Badan Akreditasi Nasional Perguruan Tinggi, Nomor: 017/BANPT/Ak-XV/S1/VI/2012 Tentang Status, Nilai, Peringkat, dan Masa Berlaku Hasil Akreditasi Program Sarjana Perguruan Tinggi, 29 Juni 2012.

Learning Center LDK UNJ. (2010): Buku Panduan Mentoring. Jakarta; LDK UNJ.

Marzuki. (1997): "Pendidikan Agama Islam di Perguruan Tinggi Umum dan Pemberdayaan Masyarakat Indonesia". Cakrawala Pendidikan. No.1, Tahun XVI: 93-101.

Masyhur, As-Syaikh Mushthafa. Amal Jama'i, Gerakan Bersama. versi pdf http:// fsialbiruni-ftunj.blogspot.co.id/2012/09/ download-materisoftware-tarbiyahkampus.html, pada 2 September 2015.

Muzakir, Ali. (2013): “Tipologi Literatur Keagamaan Aktivis Muslim Kampus di
Kota Jambi", Jurnal Lektur Keagamaan, Vol. 11(2): 117-130.

Nur, Mahmudah. (2015): “Rancangan Proposal Penelitian Bacaan Keagamaan Aktivis Kampus di Perguruan Tinggi Umum". Balai Litbang Agama Jakarta.

Qutb, Syed. (t.t): Petunjuk Sepanjang Jalan (versi pdf). Diunduh dari http://blog. uny.ac.id/mohkhairudin/files/2012/02/ Petunjuk-Sepanjang-Jalan-Sayyid-QuthbEdisi-Indonesia.pdf pada 02 September 2015.

Saefullah, Asep. (2008): "Peta Lektur Keagamaan pada Kelompok Keagamaan Islam di IPB: Benang Merah Gerakan Islam Asasi". Jurnal Lektur Keagamaan, Vol. 6 (1): 91-124.

Saifuddin. (2011): "Radikalisme di Kalangan Mahasiswa (Sebuah Metamorfosa Baru)". Analisa, Jurnal Studi Keislaman. Vol. 9(1): 17-32.

Santoso, Arif Gunawan. (2015): "Strategi Mobilisasi Sumber Daya Fundamentalisme Islam: Studi Hisbut Tahrir Indonesia", Dialog, Vol. 38 (2): 221-236.

as-Sīsi, Abbas. (1416 H./1995 M): At-Thariq ilal Qulūb, Bagaimana Menyentuh Hati, Kiat-Kiat Memikat Objek Dakwah". versi pdf dalam www.dakwah.info.

Syahidin, dkk.. (2014): Pendidikan Agama Islam untuk Perguruan Tinggi. Jakarta: Direktorat Pembelajaran dan Kemahasiswaan, Direktorat Jenderal Perguruan Tinggi, Kementerian Pendidikan dan kebudayaan.

al-Tilmisani, Umar. (2008): Hasan al-Banna Sang Inspirator. Penerjemah: Arya Noor Amarsyah. Jakarta: Kuwais International. Versi pdf disebarluaskan melalui portal Islam: http://www.Kaunee. com.

Tim Penelitian Lembaga Penelitian Institut Pertanian Bogor. (2003): “Kelompok 
Studi Keagamaan di Kampus Perguruan Tinggi Umum", Edukasi, Vol. I (4): 58-72.

Tim Penyusun. (2008): Kamus Besar Bahasa Indonesia. Jakarta: Balai Pustaka.

Tim Penyusun. (2014): Pedoman Akademik 2014/2015 Fakultas Ilmu Pendidikan Universitas Negeri Jakarta. Jakarta: Univrsitas Negeri Jakarta.

Tim Penyusun. (2016): Pedoman Akademik 2016-2017 Fakultas Ilmu Sosial. Jakarta: Universitas Negeri Jakarta.

\section{Wawancara}

Fadila,Hadi.(2015):Wawancara.11September, di Kampus UNJ, Rawamangun, Jakarta Timur.

al-Hadi, Hadi. (2015): Wawancara. 7 September, di Kampus UNJ, Rawamangun, Jakarta Timur.

Kurniawan, Rizki. (2015): Wawancara. 7 September, di Kampus UNJ, Rawamangun Jakarta Timur.

\section{Situs Internet}

"Antisipasi Pikiran Sesat, LDK UNJ Aktif Gelar Kajian", berita dalam https:// www.islampos.com/antisipasi-pemikiransesat-ldk-unj-aktif-gelar-kajian-77871/, published Jumat, 13 Zulkaedah 1436/28 Agustus 2015. Diakses 02 September 2015.

Burhani, Ruslan. (2011): “Dosen ilmu agama Islam diminta dorong karakter mahasiswa"http://www.antaranews.com/ berita/285219/dosen-ilmu-agama-islamdiminta-dorong-karakter-mahasiswa, Kamis, 17 November 2011. 20:11 WIB. Diakses 02/09/2015.

Chaniago, Fadhilah. (2015): "Resume KIU: Generasi Tafaquh Fiddin", dalam http:// salimunj.com/s2/2015/02/26/resume-kiugenerasi-tafaquh-fiddin/, February 26th, 2015. Diakses 5 September 2015. http://fis.unj.ac.id/?page_id=129. Diakses 02/09/2015.

http://fsialbiruni-ftunj.blogspot. co.id/2012/09/download-materisoftwaretarbiyah-kampus.html, "Download Materi,Software Tarbiyah, Kampus \& Keislaman." Diakses 02/09/2015.

http://kupasunj.tumblr.com/ Diakses 02/09/2015.

http://salimunj.com/s2/2012/05/21/ lembaga-semi-otonom-ldk-unj/ Diakses 02/09/2015.

http://salimunj.com/s2/2012/05/23/lembagadakwah-fakultas/. Diakses 02/09/2015.

http://salimunj.com/s2/category/c82-tsaqafahislamiyah/. Diakses 02/09/2015.

Ilham. (2015): "Ketua LDK Salim UNJ: Istilah Islam Nusantara Memecah Belah Kaum Muslimin," alam http://www. sharia.co.id/ketua-ldk-salim-unj-istilahislam-nusantara-memecah-belah-kaummuslimin.html, 28 Agustus 2015. Diakses 05/09/2017.

"Ma'rifatul Islam", http://salimunj.com/ s2/2012/06/22/marifatul-islam/, June 22nd, 2012, BangSalim, "Bidang Akidah". Dikases 5 September 2015.

"Mentoring", http://fsialbiruni-ftunj.blogspot. co.id/2012/08/mentoring.html. Diakses 07/09/2015.

"Profil LDK Salim UNJ", http://salimunj.com/ s2/2012/05/12/profil-ldk-salim-unj/. Lihat juga http://www.unj.ac.id/pr3/?page_ $i d=457$. Diakses 07/09/2015.

Ryansyah, Andi. (2015): "Jilbab dan MPA di FMIPA UN", dalam http://kupasunj. tumblr.com/. Diakses 02/09/2015.

Susanti, Aisyah Elia. (2012): "Menjadi Aktivis Prestatif”, http://salimunj.com/ s2/2012/09/05/menjadi-aktivis-prestatif/, upload September 5th, 2012, by BangSalim. Diakses 2 September 2015.

Tim Penyusun, "Sejarah UNJ", http://www. unj.ac.id/halaman/profil/sejarah, Jakarta: Admin. Web UNJ. Dikases 07/09/2015. 